\title{
Bacterial and archaeal spatial distribution and its environmental drivers in an extremely haloalkaline soil at the landscape scale
}

\author{
Martha Adriana Martínez-Olivas ${ }^{1}$ ， Norma G Jiménez-Bueno ${ }^{1}$ ， Juan Alfredo Hernández-García ${ }^{2}$, Carmine \\ Fusaro $^{3}{ }^{\text {, }}$ Marco Luna-Guido ${ }^{1}$, Yendi E Navarro-Noya ${ }^{4}$, Luc Dendooven ${ }^{\text {Corresp. }}{ }^{1}$ \\ 1 Laboratory of Soil Ecology, Cinvestav, Mexico City, Mexico \\ 2 Laboratory of Biological Variation and Evolution, Department of Zoology, Escuela Nacional de Ciencias Biológicas, Instituto Politecnico Nacional, Mexico \\ City, Mexico \\ 3 Centro Tlaxcala de Biología de la Conducta, Universidad Autónoma de Tlaxcala, Tlaxcala, Tlaxcala, Mexico \\ ${ }^{4}$ Cátedras Conacyt, Universidad Autónoma de Tlaxcala, Tlaxcala, Tlaxcala, Mexico \\ Corresponding Author: Luc Dendooven \\ Email address: dendooven@me.com
}

Background. A great number of studies have shown that the distribution of microorganisms in the soil is not random, but that their abundance changes along environmental gradients (spatial patterns). The present study examined the spatial variability of the physicochemical characteristics of an extreme alkaline saline soil and how they controlled the archaeal and bacterial communities so as to determine the main spatial community drivers. Methods. The archaeal and bacterial community structure, and soil characteristics were determined at 13 points along a $211 \mathrm{~m}$ transect in the former lake Texcoco. Geostatistical techniques were used to describe spatial patterns of the microbial community and soil characteristics and determine soil properties that defined the prokaryotic community structure. Results. A high variability in electrolytic conductivity (EC) and water content (WC) was found. Euryarchaeota dominated Archaea, except when the EC was low. Proteobacteria, Bacteroidetes and Actinobacteria were the dominant bacterial phyla independent of large variations in certain soil characteristics. Multivariate analysis showed that soil WC affected the archaeal community structure and a geostatistical analysis found that variation in the relative abundance of Euryarchaeota was controlled by EC. The bacterial alpha diversity was less controlled by soil characteristics at the scale of this study than the archaeal alpha diversity. Discussion. Results indicated that WC and EC played a major role in driving the microbial communities distribution and scale and sampling strategies were important to define spatial patterns. 


\section{Bacterial and archaeal spatial distribution and its environmental}

\section{2 drivers in an extremely haloalkaline soil at the landscape scale}

4 Martha Adriana Martínez-Olivas ${ }^{1}$, Norma Guadalupe Jiménez-Bueno ${ }^{1}$, Juan Alfredo Hernández-

5 García $^{2}$, Carmine Fusaro ${ }^{3}$, Marco Luna-Guido ${ }^{1}$, Yendi E. Navarro-Noya ${ }^{4}$, Luc Dendooven ${ }^{1}$, 6

$7 \quad{ }^{1}$ Laboratory of Soil Ecology, Cinvestav, Mexico City, Mexico.

$8{ }^{2}$ Laboratory of Biological Variation and Evolution, Department of Zoology, Escuela Nacional

9 de Ciencias Biológicas, Instituto Politécnico Nacional, Mexico City, Mexico.

$10{ }^{3}$ Centro Tlaxcala de Biología de la Conducta, Universidad Autónoma de Tlaxcala, Tlaxcala,

11 Tlaxcala, Mexico.

$12{ }^{4}$ Universidad Autónoma de Tlaxcala, Tlaxcala, Tlaxcala, Mexico.

13

14 Corresponding Author:

15 Luc Dendooven ${ }^{1}$

16 Email address: dendooven@me.com 


\section{ABSTRACT}

19 Background. A great number of studies have shown that the distribution of microorganisms in 20 the soil is not random, but that their abundance changes along environmental gradients (spatial 21 patterns). The present study examined the spatial variability of the physicochemical

22 characteristics of an extreme alkaline saline soil and how they controlled the archaeal and

23 bacterial communities so as to determine the main spatial community drivers.

24 Methods. The archaeal and bacterial community structure, and soil characteristics were 25 determined at 13 points along a $211 \mathrm{~m}$ transect in the former lake Texcoco. Geostatistical 26 techniques were used to describe spatial patterns of the microbial community and soil 27 characteristics and determine soil properties that defined the prokaryotic community structure. 28 Results. A high variability in electrolytic conductivity (EC) and water content (WC) was found. 29 Euryarchaeota dominated Archaea, except when the EC was low. Proteobacteria, Bacteroidetes and Actinobacteria were the dominant bacterial phyla independent of large variations in certain soil characteristics. Multivariate analysis showed that soil WC affected the archaeal community structure and a geostatistical analysis found that variation in the relative abundance of

33 Euryarchaeota was controlled by EC. The bacterial alpha diversity was less controlled by soil 34 characteristics at the scale of this study than the archaeal alpha diversity.

35 Discussion. Results indicated that WC and EC played a major role in driving the microbial communities distribution and scale and sampling strategies were important to define spatial 37 patterns. 
INTRODUCTION

40 Soil is spatially and temporally the most heterogeneous environment on earth. It provides

41 adequate surroundings for a large variety of microorganisms, whose interactions with

42 environmental factors (detritus sphere, $\mathrm{pH}$, hydrosphere, etc.) make soil an extremely complex

43 reactor. At a global scale, the weather forms the soil, and as the scale decreases, the soil structure

44 defines the microbial microenvironment diversity (Lavalle \& Spain, 2003; Martiny et al., 2006;

45 Legendre \& Legendre, 2012).

46 Several studies have shown that in soil the distribution of microorganisms is not random, but

47 their abundance and activity changes with environmental gradients forming spatial patterns. The study of microbial spatial patterns provides important information that can help to 1) predict the spatial distribution of microorganisms, 2) understand the diversity moulding and evolutionary processes, 3) understand the impact of human activities on biodiversity at different scales, 4) lead

51 to the development of strategies for ecosystem management and 5) determine how

52 microorganisms distributed in a specific area contribute to biogeochemical processes (Fierer,

53 2008; Philippot et al., 2009; Bru et al., 2011; Fakruddin et al., 2013; Rousk \& Bengston, 2014).

54 The use of omic techniques together with the application of geostatistical tools allows for the 55 determination of the distribution patterns of microorganisms at different scales and their 56 relationship with environmental or physicochemical factors (Franklin \& Mills, 2003; Philippot et 57 al., 2009). A high correlation between microbial communities and soil $\mathrm{pH}$, electrolytic 58 conductivity (EC) and salinity, have been found in several studies at scales that vary from a few 59 cm's to km's in a wide range of soil types (Andrew et al., 2012; Inskeep et al., 2013; Crits60 Chistoph et al., 2013). 
61

62

A large number of novel members of the Archaea Domain have been detected in extreme saline environments (Oren, 2003; Grant et al., 2011; Oren, 2016). Halophilic Archaea of the Halobacteriaceae family are often the most dominant halophilic organisms in extreme saline environments (Oren, 2003; Grant et al., 2011). Most of its members can grow in at least 100-150 g salts $1^{-1}$. The hypersaline environments studied are mostly aqueous, such as solar salterns, dead sea and alkaline lakes in Egypt (Oren, 2016), but only a few have focused on soils or sediments. In some of these studies, Archaea diversity and richness increased with salinity or electrolytic conductivity (EC) and correlated with $\mathrm{pH}$, organic $\mathrm{C}$ and particle size, and Euryarchaeota were the dominant archaeal phylum (Hollister et al., 2010; Canfora et al., 2015). Weather conditions can alter soil salinity and hence time and spatial variability are determinant factors (Budakoglu et al., 2014; Canfora et al., 2015).

The drained soil of the former lake Texcoco has characteristics that make it a unique and heterogeneous environment (Dendooven et al., 2010). In previous studies with soil of the former lake Texcoco, a great variability in $\mathrm{pH}$, i.e. 8.5-10.5 (Navarro-Noya et al., 2015), 7.8-10.0 (Valenzuela-Encinas et al., 2009) and 7.8 (Valenzuela-Encinas et al., 2012) and EC (0.7-157.2 Navarro-Noya et al., 2015; 0.68-159 Valenzuela-Encinas et al., 2009 and 0.68 ValenzuelaEncinas et al., 2012) was found. Valenzuela-Encinas et al. (2008) and Navarro-Noya et al. (2015) studied the archaeal and bacterial diversity and phylogeny in soil of the former lake Texcoco. They found that Euryarchaeota dominated the archaeal population and Proteobacteria the bacterial population. Valenzuela-Encinas et al. (2009) found that the dominant bacterial groups in this area belonged to the Alpha- and Gammaproteobacteria (mostly members of Halomonas), Bacteroidetes and Cyanobacteria. They also found that bacterial diversity and richness were greater in soil of the former lake of Texcoco with $56 \mathrm{dS} \mathrm{m}^{-1}$ EC compared with 
84 those of soil with $159 \mathrm{dS} \mathrm{m}^{-1}$ EC values. No study, however, described how spatial variability

85 would alter the microbial diversity in the former lake bed and if similar groups dominated along

86 a gradient. The objective of this work was to study the spatial distribution of the microbial

87 communities in soil of the former Lake Texcoco with a high $\mathrm{pH}$ and a high EC and to determine

88 the soil characteristics that controlled their distribution. We hypothesized that in a $200 \mathrm{~m}$ transect

89 in soil of the former lake Texcoco, the soil microbial communities would be controlled by the 90 variation in $\mathrm{pH}$ and $\mathrm{EC}$.

91

92

MATERIAL AND METHODS

93 Site description and Soil sampling

94 The sampling area in the former lake bed was defined where a high $\mathrm{pH}$ and EC were found 95 previously $\left(19.30^{\circ} \mathrm{N}, 98.53^{\circ} \mathrm{W}\right)$. Soil was collected on August $22^{\text {nd }} 2014$. The temperature was

$9619^{\circ} \mathrm{C}$ during sampling shortly after a period of precipitation, i.e. $189.2 \mathrm{~mm}$, according to the

97 national meteorological system (Mexico) (http://smn.cna.gob.mx/es/).

98 The salt content of the former lake is the result of upwelling brackish groundwater,

99 preferential water infiltration, evaporation and salt leaching especially during the rainy season.

100 Some parts of the former Texcoco lake bed have been drained, which contributed to variations in

101 salt content (Dendooven et al., 2010). Distichlis spicata L., a salt resistant grass, can be found in

102 patches in the former lake bed. It forms extensions from its base over the soil when the salt

103 content is too high. Its decomposition will be hampered in those parts where the salt content is

104 too high.

105 Soil was sampled from 13 points along a $211 \mathrm{~m}$ transect. A GPS unit (eTrex Vista® C

106 Garmin, Olathe, Kansas, USA) was used to determine spacing between the sampling points. The 
$1071 \mathrm{~cm}$ topsoil was removed and approximately $500 \mathrm{~g}$ soil samples were collected from the 1-15

$108 \mathrm{~cm}$ layer. The samples were $2 \mathrm{~mm}$ sieved. A $20 \mathrm{~g}$ soil sub-sample was used to extract DNA and

109 the rest was dried at room temperature for $24 \mathrm{~h}$. The air-dried soil was analysed for $\mathrm{pH}$, water

110 content (WC), EC, particle size distribution, total carbon and inorganic carbon.

111 Details and references to the methods used can be found in Franco-Hernández et al. (2010).

112 Soil $\mathrm{pH}$ was measured in 1:2.5 soil-H2O suspension using a glass electrode, the EC was

113 determined in a saturated soil-paste extract (Rhoades et al., 1989) and total C was determined by

114 oxidation with potassium dichromate $\left(\mathrm{K}_{2} \mathrm{Cr}_{2} \mathrm{O}_{7}\right)($ Amato, 1983). The inorganic $\mathrm{C}$ was determined

115 by adding $5 \mathrm{ml} \mathrm{HCl} 5 \mathrm{M}$ to $1 \mathrm{~g}$ soil and trapping the emitted $\mathrm{CO}_{2}$ in a $5 \mathrm{ml} \mathrm{NaOH}$ as described

116 by Bundy \& Bremner (1972). Soil particle size distribution was determined by the Bouyoucos

117 method (Gee \& Bauder, 1986). The WC was calculated from the weight loss after drying the

118 samples in an oven at $105^{\circ} \mathrm{C}$ for $24 \mathrm{~h}$.

119

120 DNA extraction, PCR amplification, and sequencing

121 The $20 \mathrm{~g}$ soil sub-samples were incubated separately in aerobic conditions for 7 days in a 11

122 glass jars containing a vessel with $20 \mathrm{ml} 1 \mathrm{M} \mathrm{NaOH}$ to trap the $\mathrm{CO}_{2}$ evolved and a vessel with 20

$123 \mathrm{ml}$ water to avoid water loss. This incubation was applied to minimize a possible effect of soil

124 sampling on the microbial community structure. After a week, 6 sub-samples of $0.5 \mathrm{~g}$ soil of

125 each incubated sample were taken and washed with $0.15 \mathrm{M}$ sodium pyrophosphate and $0.15 \mathrm{M}$

126 phosphate buffer ( $\mathrm{pH} 8.0)$ to remove fulvic and humic acids (Ceja-Navarro et al., 2010). Two

$1270.5 \mathrm{~g}$ sub-samples were extracted for DNA with the technique described by Valenzuela-Encinas

128 et al. (2008), two with the method of Sambrook \& Russel (2001) and two with the technique of

129 Winston \& Hoffman (1987). As such, $3 \mathrm{~g}$ soil from each sampling point was extracted for DNA, 
130 i.e. three extraction techniques applied in duplicate to $0.5 \mathrm{~g}$ soil. The duplicated extraction

131 products from the three techniques were pooled and stored at $-20^{\circ} \mathrm{C}$. A combination of several

132 soil sampling and DNA extraction strategies was used to assure the whole metagenome was

133 extracted.

134 Primers used to amplify the bacterial 16S rRNA V1-V6 gene region was targeted

135 (approximately 900 bp) using 10-bp barcoded primers 8-F (5'-AGA GTT TGA TCI TGG CTC

136 A- 3') and 949-R (5'-CCG TCW ATT KCT TTG AGT T-3'), and containing the A and B 454

137 FLX adapters (Navarro-Noya et al. 2013). The amplification program included 25 cycles of 45

$138 \mathrm{sec}$ denaturation at $94^{\circ} \mathrm{C}$, alignment at $50.2^{\circ} \mathrm{C}$ for $45 \mathrm{sec}$ and extension at $72^{\circ} \mathrm{C}$ for $1 \mathrm{~min} 30$

139 sec. Equal amounts of the product of five reactions were pooled and purified using the DNA

140 Clean \& Concentrator purification kit as recommended by the manufacturer (Zymo Research,

141 Irvine, CA, USA), and quantified using the PicoGreen ${ }^{\circledR}$ dsDNA assay (Invitrogen, Carlsbad, Ca,

142 USA) and the NanoDrop ${ }^{\circledR} 3300$ Fluorospectrometer (Thermo Scientific NanoDrop). The

143 archaeal V1-V3 region was targeted (approximately $560 \mathrm{bp}$ ), using 10-bp barcoded primers A-

144 25-F (5'- CYG GTT GAT CCT GCC RG-3') and A-571-R (5'- GCT ACG GNY SCT TTA RGC-

$1453^{\prime}$ ), and containing the corresponding A and B 454 FLX adapters. The amplification program

146 contained 30 cycles and the amplification products were treated as those of Bacteria. Purification

147 protocols and the quantification of the DNA are given in Navarro-Noya et al. (2013).

148 Sequencing was done by Macrogen Inc. (DNA Sequencing Service, Seoul, Korea) using a Roche 149454 GS-FLX Plus System pyrosequencer (Roche, Mannheim, Germany).

150

151 Microbial community analyses 
152 The analysis of the pyrosequencing data was done with the QIIME version 1.8.0 software

153 pipeline (Caporaso et al., 2010b). First, poorly and low quality sequences were removed from

154 the data set. All sequences of Archaea with length $<290$ and $>530 \mathrm{nt}$, quality score (Phred) $<25$,

155 containing homopolymers $>6$, and with 2 minimal errors in barcodes and primers and those of

156 Bacteria with length $<380$ and $>930$ nt, quality score (Phred) $<25$, containing homopolymers $>6$

157 and with 2 minimal errors in barcodes and primers, were removed.

158 The operational taxonomic units (OTUs) were defined at a $97 \%$ similarity level $\left(\mathrm{OTU}_{97}\right)$

159 using the Uclust algorithm (Edgar, 2010) and determined against the greengenes v13_5 database

160 (http://greengenes.lbl.gov/). One representative sequence of each OTU 97 was selected, i.e. rep-

161 set. Chimeric sequences were detected using the chimera slayer and removed from the rep-set

162 (Haas et al., 2011). Sequence alignments of the rep-set were done against the Greengenes core

163 set using PyNAST and filtered at a 75\% threshold (Caporaso et al., 2010a).

164 One representative sequence of each $\mathrm{OTU}_{97}$ was chosen and the taxonomic assignment was

165 determined using the naïve Bayesian rRNA classifier from the Ribosomal data project

166 (http://rdp.cme.msu.edu/classifier/classifier.jsp) (Wang et al., 2007) with a confidence threshold

167 of $80 \%$ (removing singletons and doubleton's) and based on the Greengenes v13_5 reference

168 database (DeSantis, 2006). Biological observations matrices (biom) with the taxonomic

169 assignments and metadata of the soil samples were constructed and used in further analysis.

170 The generated biom table was used to calculate the distributions at different taxonomic levels,

171 while diversity and richness estimators were determined using data filtered and rarefied

172 (Kuczynski et al., 2011). Richness estimators (Chao1, ACE), alpha diversity (Simpson, Simpson

173 E and Shannon), phylogenetic diversity (PD) and Good's coverage of counts for both Archaea

174 and Bacteria in each sample, were calculated using the QIIME 1.8 pipeline, with the 
175 alpha diversity.py script (Chao, 1984; Chazdon et al., 1998; Chao et al., 2000; Faith \& Baker,

176 2007). The biom matrices were rarefied to the minimum sequence found along the transect, 139

177 sequences for Archaea (Average: 732.462) and 125 sequences for Bacteria (Average: 302.167),

178 to normalize the sequence number for each sample creating a subsampled $\mathrm{OTU}_{97}$ table using the

179 NumPy algorithm for pseudo-random sampling. Samples with fewer sequences than the

180 requested rarefaction depth were omitted in the analysis

181 The relative abundances were calculated for $\mathrm{OTU}_{97}$ and genus taxonomic level in each sample

182 (Legendre \& Legendre, 2012).

183

184 Statistical and geostatistical analyses

185 Descriptive statistics were determined for each physicochemical parameter in the transect using

186 the R environment ( $R$ Core Team, 2014). The following statistics were applied: minimum,

187 maximum, quartiles, standard deviation, variance and normality test (Kolmogorov-Smirnoff,

188 Shapiro-Wilks and Q-Q plots). The kurtosis and skewness were calculated, and boxplot and

189 tendency graphs were made for each factor.

190 Geographic exploratory analysis was done using GeoR, gstat and sp packages in the R

191 environment to determine the spatial distribution of each physicochemical factor (values at every

192 sampled point) (Pebesma, 2004; Bivand \& Pebesma, 2005; Ribeiro \& Diglee, 2016) The Mantel

193 autocorrelograms were determined with the ncf package (Bjornstad, 2016), using 1000

194 permutations. The omnidirectional semivariograms Eq. (1), were calculated using the geoR and

195 gstat package within the R environment (Pebesma, 2004; Bivand \& Pebesma, 2005). A cloud

196 semivariogram to identify tendencies or atypical values, and a grouped semivariogram were

197 computed for fitting. The semivariograms model fit, which seeks to characterize them, 
198 describing how the parameters varied with the distance, was done using the Gstat library in the $\mathrm{R}$

199 environment.

200

$201 \quad \check{\gamma}(h)=\frac{1}{2 N(h)} \sum_{\alpha=1}^{N(h)}\left[Z\left(u_{\alpha}\right)-Z\left(u_{\alpha}+h\right)\right]^{2}$

202

203 where $\check{\gamma}(h)$ was the semivariance, $h$ distance between the sample points, $Z$ the value of

204 physicochemical factor, $N(h)$ the total pair of locations separated by a lag distance $h, Z\left(u_{\alpha}\right)$, and $Z$ $205\left(u_{\alpha}+h\right)$ values of $Z$ at positions $u_{\alpha}$ and $u_{\alpha}+h$ (Goovaerts et al., 1998).

206 Multiple correlations were done using the ncf package to select factors and to determine the 207 correlations between them (Bjornstad, 2016). The interpolation method used was a standard form 208 of kriging called ordinary kriging algorithm (Isaaks \& Srivastava, 1989; Goovaerts, 1998) in 209 which predictions are made Eq. (2):

210

$211 \hat{Z}_{O K}\left(S_{0}\right)=\sum_{i=1}^{n} w_{i}\left(S_{0}\right) * z\left(S_{i}\right)=\lambda_{0}^{T} * Z$

213 where $\lambda_{0}$ is the vector of kriging weights $\left(w_{i}\right)$ and $\mathrm{z}$ is the vector of $\mathrm{n}$ observations at primary 214 locations (Hengl, 2009). The kriging was computed for a polygon of $0.71 \mathrm{Ha}\left(7141 \mathrm{~m}^{2}\right)$ 215 composed of 3000 pixels each of $2.38 \mathrm{~m}^{2}$ around the sampling transect with the model of 216 adjusted semivariograms for selected physicochemical factors using gstat package (Pebesma, 217 2004). Validation was done by leave-one out cross validation kriging in gstat (Pebesma, 2004;

218 Hengl, 2009). The cross validation predicts the value at one location by kriging without using the 219 observed value and doing it for all the points in the dataset one at a time so each point is assessed 220 versus the whole (Hengl, 2009). Average standard error (ASE Eq. (3)) and root mean square 
221 error (RMSE, Eq. (4)) were calculated by a cross validation of predicted versus observed values.

222 The kriging interpolation was considered good when the measures ASE and RMSE assessing

223 variability of predicted values were similar. The normalized RMSE (RMSE, Eq. (5)) described

224 the consistency of the model, explaining the variation of specific parameters. A value RMSE

225 close to 40\% indicated an accurate prediction (Hengl, 2009; Chabala, Mulolwa \& Lungu, 2017).

226

$227 \quad A S E=\sqrt{\frac{1}{N}} \sum_{j=1}^{N}\left[Z^{\prime}\left(S_{j}\right)-\left(\sum_{j=1}^{N} Z^{\prime}\left(S_{j}\right) / N\right)\right]^{2}$

228

229 where $Z^{\prime}\left(S_{j}\right)$ are estimated values, $Z\left(S_{j}\right)$ observations at validation points and $\mathrm{N}$ is the number of 230 validation points.

231

232

$R M S E=\sqrt{\frac{1}{N}} \cdot \sum_{j=1}^{N}\left[Z\left(S_{j}\right)-Z^{\prime}\left(S_{j}\right)\right]^{2}$

233

$234 R M S E_{r}=\frac{R M S E}{S_{z}}$

235

236

where $\mathrm{S}_{\mathrm{z}}$ is the total variation (standard deviation).

237

The relationship between bacterial groups and physicochemical characteristics were explored with a canonical analysis of principal coordinates (CAP) in the Vegan package (Oksanen et al.

239 2017). All measured soil characteristics, i.e. $\mathrm{pH}$, water content, EC, particle size distribution

240 (sand, clay and loam), and organic and inorganic C were included in the CAP analysis. A

241 principal component analysis (PCA) was done using the packages FactoMineR (Le, Josse \& 242 Husson, 2008) while heatmaps were made using ComplexHeatmap (Gu, Eils \& Schlesner, 2016). 
243 The Spearman test was used to calculated correlations between taxonomic groups and the soil

244 characteristics. The corSelect and multicol analysis in the Fuzzysim package (Barbosa, 2016)

245 and BIOENV in Vegan package in $\mathrm{R}$ were used also to identify the variables with the least

246 multicollinearity, those that showed direct relationships with communities and finally those that

247 combined affected most the taxonomic groups.

248

249 Data accessibility

250 Sequences obtained in this study were submitted to the NCBI Sequences Read Archive

251 associated with the BioProject ID PRJNA414475 under the accession numbers:

252 [SAMN07840001] to [SAMN07840013] for Archaea and [SAMN07840024] to

253 [SAMN07840035] for Bacteria.

254

255 RESULTS

256 Soil characteristics

257 The $\mathrm{pH}$ varied between 10.3 and 10.6, while the soil WC between $13.3 \%$ and 55.5\% (Table S1).

258 The EC was highly variable along the transect and ranged from 7.7 to $179.8 \mathrm{dS} \mathrm{m}^{-1}$ as was the 259 organic $\mathrm{C}$, which ranged from $4.5-26.3 \mathrm{~g} \mathrm{~kg}^{-1}$ dry soil. The particle size distribution showed less

260 variation and the soil texture ranged from sandy clay loam to loamy clay. Normality tests showed

261 that each parameter was normally distributed without any tendency

262 (10.6084/m9.figshare.6357344 for descriptive statistics table and 10.6084/m9.figshare.6349547

263 for Q-Q plots).

264 As was mentioned in the site description, some parts of the former Texcoco lake bed have

265 been drained, which contributed to variations in salt content (Dendooven et al., 2010). 
266 Concordantly, the WC was highly variable upon soil sampling. The particle size distribution was

267 more constant although large variations in the clay content have been found in earlier studies

268 (Dendooven et al., 2015). The organic C content was also highly variable and ranged from an

269 organic poor soil $\left(4.5 \mathrm{~g} \mathrm{C} \mathrm{kg}^{-1}\right)$ to an organic rich one $\left(26.3 \mathrm{~g} \mathrm{~kg}^{-1}\right)$. The combination of variable

270 plant material deposition and mineralization generated the large variability in soil organic matter

271 content.

272

\section{Archaeal community structure}

274 The largest Shannon diversity index was found in sample Tx-007 (5.87) and the lowest in sample

275 Tx-008 (2.10), while the highest Chao1 richness in sample Tx-011 (300) and the lowest in

276 sample Tx-012 (30) (Table 1). The PD ranged from 1.58 in sample Tx-012 to 3.82 in sample Tx-

277 007. Diversity indexes were positively significantly correlated with the soil WC (Shannon $\mathrm{r}=$

278 0.74) and the inorganic $\mathrm{C}$ content (Shannon $\mathrm{r}=0.71$ ), and significantly negatively correlated

279 (Shannon $\mathrm{r}=-0.57)$ with the silt content $(p<0.05)$.

280 Overall, sequences belonged to 2 archaeal phyla, 4 classes, 5 orders, 5 families and 9 genera

281 (Table 1). The number of archaeal phyla in each sample ranged from 1 to 2, classes from 2 to 4 ,

282 orders from 2 to 4 , families from 1 to 4 and genera from 3 to 6 . Phylotypes belonging to the

283 Euryarchaeota (mostly Halobacteriales) were the most abundant, but in two samples (Tx-008 and

284 Tx-012) the relative abundance of Thaumarchaeota (mostly Nitrososphaerales) was greater

285 (Figure S1). Members of the Halobacteriaceae were found in each soil sample and were often the 286 most abundant, with a relative abundance that ranged from $15.8 \%$ in sample Tx- 012 to $98.7 \%$ in

287 sample Tx-002. The Nitrososphaeraceae (mostly Candidatus Nitrososphaera) dominated in 
288 sample Tx-008 with relative abundance of 78.4\%. Phylotypes could be assigned to eight archaeal 289 genera with Candidatus Nitrososphaera, Cenarchaeum and Natronomonas the most abundant.

290 The relative abundance of Cenarchaeum was positively significantly correlated with sand 291 content $(\mathrm{r}=0.76)$ and that of Natronomonas negatively $(\mathrm{r}=-0.67)$ with $\mathrm{EC}(p<0.01)$ (Figure

292 1A). The CAP grouped most soil samples together in the upper and lower left quadrant, except

293 for samples Tx-008 and Tx-012 (Figure 1B). Samples Tx-008 and Tx-012 were characterized by

294 a larger value for dimension1 (CAP1), i.e. a high relative abundance of Candidatus

295 Nitrososphaera, a high silt content and a lower pH, EC and WC. The other soil samples were

296 separated by differences in the relative abundance of most other archaeal genera, e.g.

297 Haloterrigena and Halostagnicola, and differences in soil characteristics, such as organic and

298 inorganic C, clay and sand content.

299 According to BIOENV analysis, a combination of WC, $\mathrm{pH}$ and clay content was the best

300 subset to explain the archaeal community composition (Table S4).

301

302 Bacterial communities structure

303 Alpha diversity parameters indicated that sample Tx-007 had the highest diversity (highest

304 Shannon index) (Table 2). The Chaol richness estimator ranged from 70 to 349.14, while the PD 305 index from 4.95 to 7.37. Sample Tx-009 showed the highest PD. No significant correlation was 306 found between the alpha diversity parameters and the measured soil characteristics. The 307 estimated number of bacterial species was higher in sample Tx002 than in sample Tx012 based 308 on both Chao1 and the abundance-based coverage estimator (ACE) species richness estimators. 309 Kalwasinska et al. (2017) reported also large differences in the number of estimated species in 310 different layers of a saline soda lime sediment in Poland. The Shannon and Simpson reciprocal 
311 indices were the lowest in Tx001 and Tx010 samples. Sample Tx010 had the highest EC value,

312 so the extreme hypersalinity affected the bacterial diversity.

313 Overall phylotypes belonged to 20 bacterial phyla, 48 classes, 57 orders, 68 families and 49

314 genera. The most abundant phyla in the samples were Actinobacteria followed by Proteobacteria

315 and Gemmatimonadetes (Figure S2). Chlorobi and Firmicutes showed the largest variability in

316 relative abundance along the transect. Members of Euzebya (Actinobacteria) were the most

317 abundant, followed by KSA1 (Bacteroidetes) and Bacillus (Firmicutes) (Figure S3).

318 The relative abundance of Chlorobi was significantly negatively correlated with the loam

319 content $(\mathrm{r}=-0.74)$ and positively with WC $(\mathrm{r}=0.73)(p<0.01)$, while Spirochaetes were

320 significantly and positively correlated with inorganic $\mathrm{C}(\mathrm{r}=0.62, \mathrm{p}<0.05)$ (Figure $2 \mathrm{~A})$. The WC

321 was significantly correlated with the relative abundance of Chlorobi $(r=0.73, p<0.05)$ and

322 Proteobacteria $(\mathrm{r}=-0.68, \mathrm{p}<0.05)$. Chlorobi were correlated significantly with most of soil

323 characteristics, positively with sand and inorganic $\mathrm{C}$ content and negatively with loam content

324 (Figure 2A) $(\mathrm{p}<0.05)$. The relative abundance of the genus B-42 was significantly and negatively

325 correlated with organic $\mathrm{C}(\mathrm{r}=-0.68)$, KSA1 positively $(\mathrm{r}=0.89)$ with WC and Methylonatrum

326 positively $(\mathrm{r}=0.54)$ with inorganic $\mathrm{C}(p<0.01)$ (Figure $2 \mathrm{~B})$. The CAP of the bacterial phyla and

327 the soil characteristics separated soil samples Tx-008 and Tx-012 from the other samples (Figure

328 3). Samples Tx-008 and Tx-012 were characterized by a larger relative abundance of

329 Proteobacteria (Figure 3A). The CAP analysis with the bacterial genera showed that samples Tx-

330008 and Tx-012 had a larger relative abundance for Amaricoccus, Kaistobacter, Paracoccus and

331 Pontibacter than the other samples (Figure 3D). Generally, the combination of WC, EC and silt

332 content were the parameters that best correlated with the relative abundance of the bacterial

333 phyla (Table S4). 
334 The ratios between the different alpha diversity indexes of Archaea/Bacteria were calculated.

335 In Tx008, the diversity of Bacteria was higher than that of Archaea (Shannon index ratio 0.37)

336 and the bacterial richness was larger than that of Archaea in Tx012 (0.43 Chao1 and ACE). In

337 Tx011, the archaeal richness was larger than that of Bacteria (2.31 for the Chao1 index and 1.70

338 for the ACE index). The locations Tx001, Tx004, Tx007 and Tx009 had a similar diversity for

339 Archaea and Bacteria.

340 This dominance of Bacteria over Archaea was detected in sites with the lowest EC, while the

341 opposite was observed in sites with high EC. The Spearman correlation for the ratio of archaeal

342 versus bacterial diversity was positive with $\mathrm{WC}(\mathrm{r}=0.86, \mathrm{p}<0.05)$ and inorganic $\mathrm{C}(\mathrm{r}=0.67$,

$343 \mathrm{p}<0.05)$, and negative with the loam content $(\mathrm{r}=-0.81, \mathrm{p}<0.05)$. A positive correlation was found

344 for the ratio of archaeal versus bacterial richness with $\mathrm{EC}(\mathrm{r}=0.73, \mathrm{p}<0.05)$.

345

\section{Geographical situation of physicochemical parameters}

347 The transect followed a diagonal orientated from Northwest to Southeast with some salt crusts

348 and patches of vegetation. Mantel autocorrelograms showed significantly positive and negative

349 spatial autocorrelations at certain distance classes along the transect thus describing a spatial

350 periodic structure $(p<0.05)$. Cloud semivariograms for the physicochemical factors did not show

351 atypical values or tendencies. For the pooled variograms, the model that best fitted the empirical

352 semivariogram of each soil characteristic was periodic, i.e. with presence of patches. The

353 calculated sill, rank, nugget and ratio nugget/sill values of each parameter are given in Table S2.

354 Organic and inorganic C content, clay, silt, WC and EC showed a high spatial autocorrelation

355 (nugget/sill ratio $<0.25$ ) while $\mathrm{pH}$ and sand showed a medium spatial dependence (nugget/sill

356 ratio between 0.25 and 0.75 ). Soil characteristics have a high spatial autocorrelation if the 
357 nugget/sill ratio $<0.25$, medium if between 0.25 and 0.75 , and low $>0.75$ (Cambardella et al., 358 1994).

359

360 Interpolated mapping of physicochemical factors

361 The studied soils were characterized as alkaline and defined as mainly sandy clay loam. Low pH 362 values $(<10.2)$ were predicted in a delimited area of approximately $180 \mathrm{~m}^{2}$, located in the south363 eastern part of the polygon, but the variation of $\mathrm{pH}$ values across the predicted area were low.

364 The predicted EC values were the lowest $\left(<7 \mathrm{dS} \mathrm{m}^{-1}\right)$ in the south-eastern part of the polygon and 365 for a $300 \mathrm{~m}^{2}$ area near to the centre of the sampling transect (501110 - 501155 Easting and $3662157425-2157475$ Northing). These areas with low EC were visually correlated with the 367 vegetation patch and with a high abundance of Thaumarchaeota. The predicted WC was more 368 heterogeneous distributed spatially with values that ranged from 10 to $70 \%$. The lowest WC was 369 predicted in the same south-eastern part of the polygon and coincided with the lowest EC 370 (around site Tx-012). The highest WC values (70\%) were predicted at the north and south edges 371 of the polygon. Inorganic $\mathrm{C}$ content was homogeneous across the sampling transect as the 372 standard deviation of the interpolated parameters was low (1.95). The organic C content showed 373 more variation (ranged from 5 to $25 \mathrm{~g} \mathrm{Kg}^{-1}$ ) with the highest values in the southeast of the 374 polygon and the lowest around Tx008. Cross validation showed that some places (8-16\%) were 375 over- or underestimated for almost all physicochemical parameters. The ASE and RMSE were 376 similar for $\mathrm{pH}$ and $\mathrm{WC}$, but not for $\mathrm{EC}$, and inorganic $\mathrm{C}$, clay and silt content (Table S3). This 377 confirmed variability in the predicted values for almost all measured soil characteristics. 
The RMSE $E_{\mathrm{r}}$ for WC was 1.108 and 1.378 for clay content indicating that the model accounted

379 for less than $50 \%$ of the variability at the validation points (Table S3). As such, the predictions

380 are not fully satisfactory for these soil characteristics.

381

382 Distribution models for Bacteria and Archaea

383 The ratio of the Shannon diversity of Archaea versus Bacteria across the predicted area ranged

384 from 0 to 1 . At the centre of the surrounding transect, i.e. around site Tx-007, a higher archaeal

385 diversity was predicted (Figure S4). Distribution of Thaumarchaeota showed two patches of high

386 abundance within the prediction area that correlated negatively with the predicted abundance

387 distribution of Euryarchaeota and negatively with predicted EC values (Figure 4). Euryarchaeota

388 were found along the whole prediction area with the lowest abundances in patches with high

389 abundance of Thaumarchaeota. The richness and diversity prediction for Bacteria (Chao1

390 estimator and Shannon index) showed the highest values in patches around sites Tx-012 and Tx-

391006 where EC and pH were lowest. A higher relative abundance of Proteobacteria and a lower

392 one for Actinobacteria was predicted around Tx-012 (Figure 5) The ASE and RMSE were

393 similar for most communities except for bacterial richness (Chao1). The $R M S E_{r}$ was greater than

$39470 \%$ for archaeal phyla and some Bacteria indicating that the predictions are not fully

395 satisfactory for those communities.

396 Sudden changes in the relative abundance of bacterial and archaeal groups were predicted

397 especially where EC and WC were lower. It is possible that transition zones of microbial

398 distribution may be more easily observed at shorter distances than those considered in the present 399 study. 


\section{DISCUSSION}

\section{Archaeal community structure}

403 Euryarchaeota was the dominant phylum across the sampling transect except for soil with a 404 lower EC (Tx008 and Tx012) where Thaumarchaeota dominated. These results are consistent 405 with other studies of alkaline and hyper-saline soils and sediments, where Euryarchaeota are the 406 dominant phylum, with Halobacteriales the most abundant order (Hollister et al., 2010; Ma \& 407 Gong et al., 2013; Budakoglu et al., 2014; Vogt et al., 2017). Euryarchaeota were often the most 408 abundant in the Texcoco soil (Valenzuela-Encinas et al., 2012; Navarro-Noya et al., 2015) 409 although Thaumarchaeota dominated in soils with lower EC, pH and clay content (Wessén et al., 410 2011; Hatzenpichler, 2012; Webster et al., 2015)

411 The lowest values of archaeal diversity and richness along the transect were found in the sites 412 Tx008 and Tx012. This could be explained by the abundance of Thaumarchaeota and the lowest 413 values of salinity at these sites and, probably the most oligotrophic conditions along the transect. 414 Similar results have been obtained in other studies in which it was found that soil dominated by 415 Thaumarchaeota had a lower diversity than the samples where other archaeal phyla dominated 416 (Auguet \& Casamayor, 2013; Navarro-Noya et al., 2015). The greatest diversity was found in 417 the sites Tx009 and Tx007, and the latter showed the greatest uniformity of species (Simpson E 418 Index). On the other hand, the greatest richness was found in site Tx011.

419 Numerous studies have found a strong effect of soil properties on soil microbial communities 420 (Bru et al., 2011; Shange et al., 2013; Pasternak et al., 2013; Sullivan et al., 2013). For instance, 421 archaeal ammonium oxidizers are affected by oxygen and ammonia concentrations, temperature, $422 \mathrm{pH}$ and salinity (Duff et al., 2017). Bru et al., (2011) found an effect of pH on the crenarchaeal 423 ammonia oxidizers, while Shange et al., (2013) a strong correlation between bacterial phyla, 
424 such as Bacteroidetes, Proteobacteria and Actinobacteria, and substrate availability along a land

425 use gradient. Pasternak et al. (2013) reported that abundances of microbial communities were

426 significantly correlated with soil characteristics, such as texture, organic matter and water

427 content. Sullivan et al. (2013) found a large effect of $\mathrm{pH}$, total soil S, extractable soil $\mathrm{Cu}$ and $\mathrm{Zn}$

428 on the soil microbial community structure. In this study, Cenarchaeum, a chemolithoautotrophic

429 mesophilic aerobic oxidizer of $\mathrm{NH}_{4}^{+}$(Hatzenpichler, 2012; Banerjee \& Siciliano, 2012) was

430 favoured by clayey soil whereas Natronomonas was favoured by high EC values. In this study

431 Candidatus Nitrososphaera, also an oxidizer of ammonium, dominated in soil with lower EC as

432 well as higher silt content. Both Cenarchaeum and Candidatus Nitrososphaera

433 (Thaumarchaeota), Archaea with a potential to oxidize ammonium, have been found in

434 hypersaline soils and marine environments (Hatzenpichler, 2012; Tolar, King \& Hollibaugh,

435 2013; Navarro-Noya et al. 2015). Members of Thaumarchaeota have been detected in

436 oligotrophic sites and have been correlated with a lower $\mathrm{pH}$ and salt content, but especially with

437 low concentrations of ammonium (Wessén et al., 2011; Marusenko et al., 2013; Bollman,

438 Bullerjahn \& Mckay, 2014).

439 Overall, archaeal diversity was favoured by soil moisture, total and inorganic C content, and

440 was negatively correlated with the silt content. Hollister et al. (2010) separated the archaeal

441 alpha diversity of hypersaline sites based mainly on the WC, i.e. distinguishing between

442 terrestrial and aquatic sites. Although they found a positive correlation of archaeal abundance

443 with EC and salinity, the most influential variable to explain differences was WC. The archaeal

444 abundance increased directly with WC and Archaea were almost absent from the terrestrial sites

445 of the sampling transect. Similar results were found in this study, as the archaeal spatial structure 446 was driven mostly by WC. 


\section{Bacterial community structure}

449 The bacterial community composition was less controlled by soil characteristics than the

450 archaeal composition in this study, as the variation in the relative abundance of most phyla was

451 low. Proteobacteria, Bacteroidetes and Actinobacteria are the dominant soil bacterial taxa in

452 saline and hypersaline soils (Ma \& Gong et al., 2013; Canfora et al., 2014; Liu et al., 2014;

453 Santini, Warren \& Kendra, 2015) as found in this study. Gemmatimonadetes detected previously

454 in hyper-saline soils (Canfora et al., 2014) and appeared not to be affected by EC. This might be

455 because some members of Gemmatimonadetes can adapt to a wide range of different conditions

456 and some species are not affected by salinity (Ma\& Gong et al., 2013). Chlorobi, often one of

457 the minor phyla, has been related frequently to organic $\mathrm{C}$ in other saline and soda sites, but also

458 in arable soils (Constancias et al., 2015). In this study, the relative abundance of Chlorobi

459 showed the largest variability along the transect and was negatively correlated with the loam

460 content and positively with WC. The relative abundance of Firmicutes was also highly variable,

461 but not controlled by soil characteristics in this ecosystem. Firmicutes are ubiquitous in soil and

462 can be found in most ecosystems (e.g. Liu et al., 2014; Santini et al., 2015).

463 Different factors, such as WC, salt content, $\mathrm{pH}$ and organic material, control the bacterial

464 community structure. Wasserstrom et al. (2017) found that WC affected the bacterial community

465 composition in a coastal dune. Microbial structure is affected by fluctuations in WC in both

466 extreme dry or wet conditions. Microorganisms need water in their environment for their normal

467 metabolic functioning and although some species have been found in extreme dry conditions,

468 their activity normally stops when the WC drops below a critical amount (Crits-Cristoph et al.,

469 2013). In wet conditions, oxygen fluxes are impeded and microbial activity changes from aerobic 
470 to anaerobic, which ultimately changes bacterial community composition. Some microorganisms

471 are strictly aerobic, so their activity is inhibited while facultative and strict anaerobes flourish.

472 Consequently, WC will control microbial community and more so in a salt rich soil where

473 osmotic pressures fluctuate more with changing WC than in a salt poor soil. For instance,

474 Hollister et al. (2010) reported that the abundance of Archaea and Bacteria was correlated to a

475 greater extent with WC than with $\mathrm{EC}$ or $\mathrm{Na}^{+}$content.

476 It has been reported that $\mathrm{pH}$ is an important driver of microbial communities distribution at

477 large scales when a gradient is present (Rousk et al., 2010; Liu et al., 2014; Constancias et al.,

478 2015). It has not been determined yet, whether the effect of $\mathrm{pH}$ is direct as a physiological

479 barrier, or indirectly through other related chemical factors. On local scale, as in this study, $\mathrm{pH}$

480 did not seem to be the main distribution driver as its variation trough the sampling transect was

481 small, i.e. 10.3 to 10.6 . This is consistent with the findings of microbial communities distribution

482 in hypersaline soils (Hollister et al., 2010; Canfora et al., 2014) and the extreme dry Atacama

483 desert (Crits-Cristoph et al., 2013).

484 Methylonatrum was first described in hypersaline lakes in Russia by Sorokin et al. (2007).

485 They described it belonging to the Gammaproteobacteria that was able to grow on $\mathrm{C}_{1}$ substrates.

486 Classified as a methylotroph genus, Methylonatrum can grow under salt saturation and

487 alkaliphilic conditions, whose optimal $\mathrm{pH}$ reaches 10.5 . In the present study, this genus showed a

488 high correlation with the $\mathrm{C}$ inorganic content, and was detected at $\mathrm{pH} 10.6$, which is consistent

489 with the findings of Simachew et al. (2015). They found Methylonatrum only in an intermediate

490 saline site (25\%) dominated by Archaea.

$491 \quad$ KSA1 and B-42, the second and third most abundant genus in this study, are little known

492 bacterial groups. They were found for the first time in lake sediments comparable to soil of the 
493 former lake Texcoco. The candidate division KSA1, the second most abundant genus found in

494 this study, was reported for the first time in a hypersaline sulphide-rich black mud environment

495 in a marsh (Tanner et al., 2000) and was classified as belonging to Bacteroidetes (McDonald et

496 al., 2012). Members of B-42 were found in freshwater sediments and activated sludge from a

497 seawater-processing wastewater treatment plant (Sánchez et al., 2011, [Genbank accession

498 number: FN598000]; Hamamura et al., 2014, [accession number: KC852965.1]; Chen et al.,

499 2015). They were found also in creosote-polluted soils (Tejeda et al., 2013, [accession number:

500 JQ771979.1]).

501 Overall the alpha diversity for bacterial communities was higher than that of Archaea. It

502 differs from other studies in hypersaline and saline environments where the diversity of Archaea

503 was larger than that of Bacteria (Canfora et al., 2015) and was more accentuated for archaeal

504 ammonia oxidizers (Wessén, 2011; Marusenko et al., 2013; Bollman, Bullerjahn \& Mckay,

505 2014). The richness of Archaea was greater in some sites (Tx-007, Tx-010, Tx-011 and Tx-013)

506 with extreme soil physicochemical characteristics (i.e. high EC and pH values) as Archaea are

507 generally better adapted to extreme halophilic environments (Oren et al., 2014).

508 A low number of sequences have been reported in similar saline environments. For instance,

509 Kalwasinska et al. (2017) reported only 70 archaeal sequences in an extreme saline soil and only

510321 bacterial OTUs, similar to those found in this study. Ma and Gong (2013) reported only

5111039 sequences for Archaea (602 OTUs assignations) after a meta-analysis of all reported

512 sequences in different saline and hyper-saline soil environments. Vogt et al. (2017) using

513 Illumina as sequencing platform, obtained a large number of sequences in hypersaline mats (up

514 to 25239 for Bacteria and 47606 for Archaea). However, they were only able to assign 221-440 
515 OTUs for Bacteria and 138-193 archaeal OTUs. The richness indices they reported were similar

516 to those found in this study.

517 The high proportion OTU/sequences might be due to a combination of factors, i.e. the

518 complexity of the sample, the ambiguity of hypervariable sites of the 16S rRNA gen, and the

519 alignment and clustering method used (Konstantinidis \& Tiedje, 2005; Chen et al., 2013; Li et

520 al., 2014; Rideout et al., 2014; He et al., 2015; Nguyen et al. 2016).

521

\section{Spatial patterns and microbial distribution}

523 An attempt was made to determine changes in microbial communities as defined by soil

524 characteristics, describing spatial distribution patterns along a sampling transect. Previous studies

525 of the extreme heterogeneous former lakebed at Texcoco (e.g. Valenzuela-Encinas et al., 2009;

526 Dendooven et al., 2010; Valenzuela-Encinas et al., 2011; Navarro-Noya et al., 2015) provided

527 indications of the scale and direction of sampling that was required to determine with

528 geostatistical and multivariate analysis the relative influence of the measured soil characteristics

529 on the microbial structure. From the previously conducted studies, the presence of gradients in

530 soil $\mathrm{pH}$ and EC values along the sampling transect was known. On the selected scale, however,

531 only a high variability of EC was found but a narrow $\mathrm{pH}$ range. Moreover, periodicities of water

532 and organic C content were observed.

533 Many studies have found that $\mathrm{pH}$ is an important driver of bacterial composition, even when

534 its variation is low (Constancias et al., 2014). However, in an extreme soil such as soil of the

535 former lake Texcoco and on a local scale, the direct influence of $\mathrm{pH}$ on microorganisms is

536 outweighed by other characteristics. The EC and WC showed a high variability along the

537 sampling transect, and the pattern of irregular distribution observed for both showed a close 
538 relationship with abrupt changes in the Archaea communities. The vegetation patches in this

539 extreme area are correlated with low EC values and a high abundance of Thaumarchaeota.

540 Thaumarchaeota members have been detected in oligotrophic sites and found to correlate with a

541 lower $\mathrm{pH}$ and salt content, especially at low ammonium concentrations (Wessén et al., 2011;

542 Marusenko et al., 2013; Bollman, Bullerjahn \& Mckay, 2014).

543 Despite the low sampling efforts, the bacterial distribution maps revealed a pattern with low

544 variability along the sampling transect for the most abundant phylum, i.e. Actinobacteria,

545 Proteobacteria and Bacteroidetes (Figure 5 B, D, E). The highest abundances for Proteobacteria

546 were observed in sites with lower EC values and the distribution of this phylum was correlated

547 positively with WC. The low variability of these taxa might be due to that some members of

548 these phyla are well adapted to salinity and alkalinity (Ma\& Gong, 2013). The variability of less

549 abundant phyla, such as Chlorobi and Firmicutes (Figure 5F), was more variable with the

550 abundance of Chlorobi correlated with most soil characteristics and Firmicutes with none.

551 The choice of scale is important to define spatial patterns. It has been observed that at a local

552 scale some factors show spatial homogeneity, as it was found with $\mathrm{pH}$ in this study. It differs

553 from large scales studies, where $\mathrm{pH}$ can be more variable and consequently be the main driver

554 for communities distribution, such as shown by Navarro-Noya et al. (2015). Spatial variability of

555 phyla at a local scale might be low as members of the same phylum can share similar

556 characteristics and metabolic activities, whereas changes in structure and composition can be

557 highlighted by abundance of order/families (Crits-Cristoph et al., 2013). Although temporal

558 variations were not investigated in this study, a strong correlation in temporal and spatial scales

559 has been reported (Lauber et al., 2013; Regan et al., 2014; Wasserstrom et al., 2017). 
560 Unfortunately, after the first sampling, it was not possible to sample the study site more

561 intensively as it was assigned to be part of the new International Airport of Mexico City.

562

\section{CONCLUSION}

564 The relative abundance of archaeal groups was controlled by soil characteristics.

565 Thaumarchaeota were more abundant in locations with the lowest EC and WC, and the presence 566 of Distichlis spicata. Consequently, abundances of Euryarchaeota were low in these points.

567 Bacteria were less affected by physicochemical factors, but the presence or absence of bacterial 568 groups was related to $\mathrm{WC}, \mathrm{pH}$ and $\mathrm{EC}$. At the scale of the present study, the main driving factor 569 to explain the microbial community structure was WC. Ordinary kriging with some of the factors 570 and response variables explained the variability in the sampling sites. For other factors and 571 response variables, however, a more intensive sampling will be required. Kriging revealed abrupt 572 changes for archaeal communities related with variability of WC and EC, but not for Bacteria.

573 The relative abundance of most bacterial groups, e.g. Actinobacteria and Proteobacteria, was less

574 variable than that of most archaeal groups, but the relative abundance of others, e.g. Chlorobi

575 and Firmicutes, was highly variable. For instance, the relative abundance of the Firmicutes

576 varied between $<0.1 \%$ in Tx008 to $25.0 \%$ in Tx 010 . It was possible to map soil community

577 distributions in extreme heterogeneous environment using a Geostatistical approach. The use of 578 novel omic tools and Geostatistical analyses can determine the functionality in an area and help 579 to design novel management practices for extreme ecosystems.

580

581 ACKNOWLEDGEMENTS 
582 The authors thank ABACUS (CONACyT) for providing time on the computer and "Comisión 583 nacional de agua (CNA)" for access to the sampling site.

584

585 


\section{REFERENCES}

587 Amato M. 1983. Determination of carbon ${ }^{12} \mathrm{C}$ and ${ }^{14} \mathrm{C}$ in plant and soil. Soil Biology \&

588 Biochemistry 15:611-612.

589

590

591

592

593

594

595

596

597

598

599

600

601

602

603

604

605

606

Andrew DR, Fitak RR, Munguia-Vega A, Racolta A, Martinson VG, Dontsova K. 2012.

Abiotic factors shape microbial diversity in Sonoran desert soils. Applied and Environmental Microbiology Journal 78:7527-7537 DOI 10.1128/AEM.01459-12.

Auguet J, Casamayor EO. 2013. Partitioning of Thaumarchaeota populations along environmental gradients in high mountain lakes. FEMS Microbiology Ecology 84:154164 DOI 10.1111/1574-6941.12047.

Banerjee S, Siciliano SD. 2012. Factors driving potential ammonia oxidation in Canadian arctic ecosystems: does spatial scale matter? Applied and Environmental Microbiology 78:34653 DOI 10.1128/AEM.06132-11.

Barbosa AM. 2016. fuzzySim: Fuzzy similarity in species distributions. R package version 1.7.8/r95. Available at https://R-Forge.R-project.org/projects/fuzzysim/.

Bivand RS, Pebesma EJ. 2005. Classes and methods for spatial data in R. R News 5 (2), Available at https://cran.r-project.org/doc/Rnews/.

Bjornstad ON. 2016. ncf: spatial nonparametric covariance functions. R package version 1.1-7. Available at https://CRAN.R-project.org/package $=n c f$.

Bollman A, Bullerjahn GS, Mckay RM. 2014. Abundance and diversity of ammonia-oxidizing Archaea and Bacteria in sediments of trophic end members of the Laurentian great lakes, Erie and Superior. PLoS ONE 9:1-11 DOI 10.1371/journal.pone.0097068. 
607 Bru D, Ramette A, Saby NPA, Dequiedt S, Ranjard L, Jolivet C, Arrouays D, Philippot L.

608 2011. Determinants of the distribution of nitrogen-cycling microbial communities at the

609 landscape scale. The International Society for Microbial Ecology Journal 5:532-542.

610 Budakoglu M, Kurt H, Karaman M, Kumru M, Kumral M, Akarsubaşi AT. 2014. Archaeal microbial diversity of hypersaline Lake Acıgöl, Denizli, Turkey. Geomicrobiology Journal 31:454-460 DOI 10.1080/01490451.2013.866994.

Bundy LG, Bremner JM. 1972. A simple titrimetric method for determination of inorganic carbon in soils. Soil Science Society of America Journal 36:273-275 DOI

615 10.2136/sssaj1972.03615995003600020021x.

Cambardella CA, Moorman TB, Novak J, Parkin TB, Karlen RF, Turco RF, Konopka AE. 1994. Field-scale variability of soil properties in central Iowa soils. Soil Science Society

Canfora L, Lo-Papa G, Antisari LV, Bazan G, Dazzi C, Benedetti A. 2015. Spatial microbial of America Journal 58:1501-1511 DOI 10.2136/sssaj1994.03615995005800050033x. community structure and biodiversity analysis in "extreme" hypersaline soils of a

\section{3} semiarid Mediterranean area. Applied Soil Ecology 93:120-129 DOI 10.1016/j.apsoil.2015.04.014.

Canfora L, Bacci G, Pinzari F, Papa GL, Dazzi C, Benedetti A. 2014. Salinity and bacterial saline soil?. PLoS ONE 9:e106662 DOI 10.1371/journal.pone.0106662.

\section{Caporaso JG, Bittinger K, Bushman FD, Desantis TZ, Andersen GL, Knight R. 2010 .}

PyNAST: A flexible tool for aligning sequences to a template alignment. Bioinformatics 26:266-267 DOI 10.1093/bioinformatics/btp636. 
629 Caporaso JG, Kuczynski J, Stombaugh J, Bittinger K, Bushman FD, Costello EK, Knight

630 R. 2010b. QIIME allows analysis of high- throughput community sequencing data intensity

631 normalization improves color calling in SOLiD sequencing. Nature Methods 7:335-336

632 DOI 10.1038/nmeth0510-335.

633 Ceja-Navarro JA, Rivera FN, Patiño-Zúñiga L, Govaerts B, Marsch R, Vila-Sanjurjo A,

634 Dendooven L. 2010. Molecular characterization of soil bacterial communities in

635 contrasting zero tillage systems. Plant and Soil 329:127-137 DOI 10.1007/s11104-009-

$636 \quad 0140-9$

637 Chabala LM, Mulolwa A, Lungu O. 2017. Application of ordinary kriging in mapping soil

$638 \quad$ organic carbon in Zambia. Pedosphere 27:338-343 DOI 10.1016/S1002-0160(17)60321-

6397.

640 Chao A. 1984. Non-parametric estimation of the number of classes in a population.

641 Scandinavian Journal of Statistics 11:265-270.

642 Chao A, Hwang WH, Yang MCK. 2000. Estimating the number of shared species in two $643 \quad$ communities. Statistica Sinica 10:227-246.

644 Chen W, Zhang CK, Cheng Y, Zhang S, Zhao H. 2013. A Comparison of Methods for

645 Clustering 16S rRNA Sequences into OTUs. PLOS ONE 8:e70837 DOI

$646 \quad 10.1371$ journal.pone.0070837

647 Chen Y, Dai Y, Wang Y, Wu Z, Xie S, Liu Y. 2015. Distribution of bacterial communities

648 across plateau freshwater lake and upslope soils. Journal of Environmental Sciences

649 43:61-69 DOI 10.1016/j.jes.2015.08.012. 
650 Crits-Christoph A, Robinson CK, Barnum T, Fricke WF, Davila AF, Jedynak B,

651 Diruggiero J. 2013. Colonization patterns of soil microbial communities in the Atacama 652 desert. Microbiome 1:1-28 DOI 10.1186/2049-2618-1-28.

653 Constancias F, Dequiedt S, Horrigue W, Saby NPA, Ranjard L. 2015. Contrasting spatial 654 patterns and ecological attributes of soil bacterial and archaeal taxa across a landscape. 655 Microbiology Open 4:518-531 DOI 10.1002/mbo3.256.

656 Dendooven L, Alcántara-Hernández RJ, Valenzuela-Encinas C, Luna-Guido M, Pérez657 Guevara F, Marsh R. 2010. Dynamics of carbon and nitrogen in an extreme alkaline 658 saline soil: A review. Soil Biology \& Biochemistry 42:865-877.

\section{Dendooven L, Ramirez-Fuentes E, Alcantara-Hernandez R, Valenzuela-Encinas C,} Sanchez-Lopez KB, Luna-Guido M, Ruiz-Valdiviezo VM. 2015. Dynamics of C-14-

Duff AM, Zhang LM, Smith CJ. 2017. Small-scale variation of ammonia oxidisers within

Desantis TZ, Hugenholtz P, Keller K, Brodie EL, Larsen N, Piceno YM. 2006. NAST : a multiple sequence alignment server for comparative analysis of 16S rRNA genes. Nucleic Acids Research 34:394-399 DOI 10.1093/nar/gk1244.

Edgar RC. 2010. Search and clustering orders of magnitude faster than BLAST. Bioinformatics 26:2460-2461 DOI 10.1093/bioinformatics/btq461. 
671 Fierer N. 2008. Microbial biogeography: patterns in microbial diversity across space and time.

672

673

674

675

676

677

678

679

680

681

682

683

684

685

686

687

688

689

690

691

692

In: Zengler BK, ed. Accessing uncultivated microorganisms: from the environment to organism and genomes and back. Washington, DC: ASM Press, 95-115.

Franco-Hernández MO, Vasquez-Murrieta MS, Patiño-Siciliano A, Dendooven L. 2010. Heavy metals concentration in plants growing on mine tailings in central México. Bioresource Technology 101:3864-3869.

Fakruddin M, Mannan KSB. 2013. Methods for analyzing diversity of microbial communities in natural environments. Ceylon Journal of Science (Biological Sciences) 42:19-33 DOI 10.4038/cjsbs.v42i1.5896.

Franklin RB, Mills AL. 2003. Multi-scale variation in spatial heterogeneity for microbial community structure in an eastern Virginia agricultural field. FEMS Microbiology Ecology 44:335-346.

Gee GW, Bauder JW. 1986. Particle size analysis. In: Klute A, ed. Methods of soil analysis, part 1, Physical and mineralogical methods, second edition. Madison, Wisconsin: Soil Science Society of America Inc., American Society of Agronomy Inc., 383-411.

Goovaerts P. 1998. Geostatistical tools for characterizing the spatial variability of microbiological and physico-chemical soil properties. Biology and Fertility of Soils 27: 315-334.

Grant WD, Pagaling E, Márquez MC, Gutiérrez MC, Cowan DA, Ma Y, Jones BE, Ventosa A, Heaphy S. 2011. The hypersaline lakes of Inner Mongolia: TheMGAtech Project. In: Ventosa A, Oren A, Ma Y, eds. Halophiles and hypersaline environments: current research and future trends. Berlín: Springer-Verlag. 65-107. 
693 Gu Z, Eils R, Schlesner M. 2016. Complex heatmaps reveal patterns and correlations in

694 multidimensional genomic data. Bioinformatics 32:2847-2849 DOI

695 10.1093/bioinformatics/btw313.

696 Haas BJ, Gevers D, Earl AM, Feldgarden M, Ward DV, Giannoukos G, Birren BW. 2011.

697 Chimeric 16S rRNA sequence formation and detection in Sanger and 454-pyrosequenced

698 PCR amplicons. Genome research 21:494-504 DOI 10.1101/gr.112730.110.Freely.

699 Hamamura N, Itai T, Liu Y, Reysenbach A, Damdinsuren N, Inskeep WP. 2014.

700

701

702

703

704

705 Identification of anaerobic arsenite-oxidizing and arsenate-reducing bacteria associated with an alkaline saline lake in Khovsgol, Mongolia. Environmental Microbiology Reports 6:476-482 DOI 10.1111/1758-2229.12144.

Harrell Jr FE, with contributions from Charles Dupont and many others. 2016. Hmisc: Harrell miscellaneous. R package version 4.0-2. Available at https://CRAN.Rproject.org/package $=$ Hmisc

706

707

708

709

710

711

712

713

714

Hatzenpichler R. 2012. Diversity, physiology, and niche differentiation of ammonia-oxidizing Archaea. Applied and Environmental Microbiology Journal 78:7501-7510 DOI 10.1128/AEM.01960-12.

He Y, Caporaso JG, Jiang XT, Sheng HF, Huse SM, Rideout JR, Edgar RC, Kopylova E, Walters WA, Knight R, Zhou HW. 2015. Stability of operational taxonomic units: an important but neglected property for analyzing microbial diversity. Microbiome 3:20 DOI 10.1186/s40168-015-0081-X

Hengl, T. 2009. A practical guide to geostatistical mapping, second edition. Amsterdam, Holland. 
715 Hollister EB, Engledow AS, Hammett AJM, Provin TL, Wilkinson HH, Gentry TJ. 2010.

716 Shifts in microbial community structure along an ecological gradient of hypersaline soils and sediments. The International Society for Microbial Ecology Journal 4:829-838 DOI

Inskeep WP, Jay ZJ, Tringe SG, Herrgård MJ, Rusch DB. 2013. The YNP metagenome

720

721

722 project: environmental parameters responsible for microbial distribution in the

Isaaks EH, Srivastava RM. 1989. Applied Geostatistics. New York, USA: Oxford University

724 press.

725

726

727

728

729

730

731

732

733

734

735

736

Yellowstone geothermal ecosystem. Frontiers in Microbiology 4:67 DOI 10.3389/fmicb.2013.00067.

\section{Kalwasinska A, Felföldi T, Szabó A, Deja-sikora E, Kosobucki P, Walczak M. 2017.}

Microbial communities associated with the anthropogenic, highly alkaline environment of a saline soda lime, Poland. Antonie van Leeuwenhoek 110:945-962. DOI 10.1007/s10482-017-0866-y.

Konstantinidis KT, Tiedje JM. 2005. Genomic insights that advance the species definition for prokaryotes. Proceedings of the National Academy of Sciences USA 102:2567-2572.

Kuczynski J, Stombaugh J, Walters WA, González A, Caporaso JG, Knight R. 2011. Using QIIME to analyze 16S rRNA gene sequences from microbial communities. Current Protocols in Bioinformatics 36:10.7.1-10.7.20 DOI 10.1002/0471250953.bi1007s36.

Lauber CL, Ramirez KS, Aanderud Z, Lennon J, Fierer N. 2013. Temporal variability in soil microbial communities across land-use types. The International Society for Microbial Ecology Journal 7:1641-50 DOI 10.1038/ismej.2013.50. 
737 Lavalle P, Spain AV. 2003. Soil Ecology New York, USA: Kluwer Academic Publishers DOI $738 \quad 10.1038 / 455724^{\mathrm{a}}$.

739 Le S, Josse J, Husson F. 2008. FactoMineR: An R package for multivariate analysis. Journal of $740 \quad$ Statistical Software 25:1-18 DOI 10.18637/jss.v025.101.

741 Legendre P, Legendre L. 2012. Numerical ecology, third edition. Amsterdam: Elsevier B.V. 742992.

743 Li SJ, Hua ZS, Huang LN, Li J, Shi SH, Chen LX, Kuang, JL, Liu J, Hu M, Shu WS. 2014. $744 \quad$ Microbial communities evolve faster in extreme environments. Scientific reports 4:6205 $745 \quad$ DOI $10.1038 /$ srep06205.

746 Liu J, Sui Y, Yu Z, Shi Y, Chu H, Jin J, Wang G. 2014. High throughput sequencing analysis

747

748

749

750

751

752

753

754

755

756

757

758

759 of biogeographical distribution of bacterial communities in the black soils of northeast China. Soil Biology \& Biochemistry 70:113-122 DOI 10.1016/j.soilbio.2013.12.014.

Ma B, Gong J. 2013. A meta-analysis of the publicly available bacterial and archaeal sequence diversity in saline soils. World Journal of Microbiology and Biotechnology 29:2325-2334 DOI 10.1007/s11274-013-1399-9.

Martiny JBH, Bohannan BJM, Brown JH, Colwell RK, Fuhrman JA, Green JL, Staley JT. 2006. Microbial biogeography: putting microorganisms on the map. Nature Reviews Microbiology 4:102-112 DOI 10.1038/nrmicro1341.

Marusenko Y, Bates ST, Anderson I, Johnson SL, Soule T, Garcia-pichel F. 2013. Ammonia-oxidizing Archaea and Bacteria are structured by geography in biological soil crusts across North American arid lands. Ecological Processes 2:1-10.

Mcdonald D, Price MN, Goodrich J, Nawrocki EP, Desantis TZ, Probst A, Hugenholtz P. 2012. An improved greengenes taxonomy with explicit ranks for ecological and 
evolutionary analyses of Bacteria and Archaea. The International Society for Microbial Ecology Journal 6:610-618 DOI 10.1038/ismej.2011.139.

762

763

764

765

766

767

768

769

770

771

772

773

774

775

776

777

778

779

780

Navarro-Noya YE, Gómez-Acata S, Montoya-Ciriaco N, Rojas-Valdez A, Suárez-Arriaga MC, Valenzuela-Encinas C, Dendooven L. 2013. Relative impacts of tillage, residue management and crop-rotation on soil bacterial communities in a semi-arid agroecosystem. Soil Biology \& Biochemistry 65:86-95 DOI

10.1016/j.soilbio.2013.05.009.

Navarro-Noya YE, Valenzuela-Encinas C, Sandoval-Yuriar A, Jimenez-Bueno NG, Marsch R, Dendooven L. 2015. Archaeal communities in a heterogeneous hypersaline-alkaline soil. Archaea 2015:1-11 DOI 10.1155/2015/646820.

Nguyen NP, Warnow T, Pop M, White B. 2016. A perspective on 16S rRNA operational taxonomic unit clustering using sequence similarity. Npj Biofilms and Microbiomes 2:16004 DOI 10.1038/npjbiofilms.2016.4

Oksanen FJ, Blanchet G, Friendly M, Kindt R, Legendre P, McGlinn D, Minchin PR, O'Hara RB, Simpson GL, Solymos P, Stevens HHM, Szoecs E, Wagner H. 2017. Vegan: Community ecology package. R package version 2.4-3. Available at https://CRAN.R-project.org/package=vegan.

Oren A. 2003. Halophilic Microorganisms and Their Environments. New York, Boston, Dordrecht, London, and Moscow: Kluwer Academic Publishers.

Oren A. 2014. Taxonomy of halophilic Archaea: current status and future challenges. Extremophiles 18:825-834 DOI 10.1007/s00792-014-0654-9. 
781 Oren A. 2016. Life in Hypersaline Environments. In: Hurst CJ, ed. Their World : A diversity of

782

783

784

785

786

787

788

789

790

791

792

793

794

795

796

797

798

799

800

801

802 microbial environments, Advances in Environmental Microbiology 1. Switzerland: Springer International Publishing, 301-339.

Pasternak Z, Al-Ashhab A, Gatica J, Gafny R, Avraham S, Minz D, Gillor O, Jurkevitch E. 2013. Spatial and temporal biogeography of soil microbial communities in arid and semiarid regions. PLoS ONE 8:e69705 DOI 10.1371/journal.pone.0069705

Pebesma EJ. 2004. Multivariable geostatistics in S: the gstat package. Computers \& Geosciences 30:683-691.

Philippot L, Bru D, Saby NPA, Cuhel J, Arrouays D, Simek M, Hallin S. 2009. Spatial patterns of bacterial taxa in nature reflect ecological traits of deep branches of the $16 \mathrm{~S}$ rRNA bacterial tree. Environmental Microbiology 11:3096-3104.

R Core Team. 2014. R: A language and environment for statistical computing. Vienna: $R$ Foundation for Statistical Computing. Available at http://www.R-project.org/.

\section{Regan KM, Nunan N, Boeddinghaus RS, Baumgartner V, Berner D, Boch S, Marhan S.} 2014. Seasonal controls on grassland microbial biogeography: Are they governed by plants, abiotic properties or both?. Soil Biology \& Biochemistry 71:21-30 DOI 10.1016/j.soilbio.2013.12.024.

Ribeiro-Jr PJ, Diglee JD. 2016. geoR: Analysis of geostatistical data. R package version 1.75.2. Available at https://CRAN.R-project.org/package $=$ geoR.

Rideout JR, He Y, Navas-Molina JA, Walters WA, Ursell LK, Gibbons SM, Chase J, McDonald D, Gonzalez A, Robbins-Pianka A, Clemente JC, Gilbert JA, Huse SM, Zhou H, Knight R, Caporaso JG. 2014. Subsampled open-reference clustering creates 
consistent, comprehensive OTU definitions and scales to billions of sequences. PeerJ

804 2:e545 DOI 10.7717/peerj.545

805

806

807

808

809

810

811

Rousk J, Bååth E, Brookes PC, Lauber CL, Lozupone C, Caporaso JG, Fierer N. 2010. Soil bacterial and fungal communities across a $\mathrm{pH}$ gradient in an arable soil. The International Society for Microbial Ecology Journal 4:1340-1351 DOI 10.1038/ismej.2010.58.

Rousk J, Bengtson P. 2014. Microbial regulation of global biogeochemical cycles. Frontiers in Microbiology 5:1-3 DOI 10.3389/fmicb.2014.00103.

Sambrook J, Russell DW. 2001. Molecular Cloning: A Laboratory Manual. Plainview, New York: Cold Spring Harbor Laboratory Press.

Sánchez O, Garrido L, Forn I, Massana R, Maldonado MI, Mas J. 2011. Molecular characterization of activated sludge from a seawater processing wastewater treatment plant. Microbial Biotechnology 4:628-642 DOI 10.1111/j.1751-7915.2011.00256.x.

Santini TC, Warren LA, Kendra E. 2015. Microbial diversity in engineered haloalkaline environments shaped by shared geochemical drivers observed in natural analogues. Applied and Environmental Microbiology 81:5026-5036 DOI 10.1128/AEM.01238-15

Shange RS, Ankumah RO, Ibekwe AM, Zabawa R, Dowd SE. 2012. Distinct soil bacterial communities revealed under a diversely managed agroecosystem. PLoS ONE 7:e40338 DOI 10.1371/journal.pone.0040338.

Shange R, Haugabrooks E, Ankumah R, Ibekwe A, Smith R, Dowd S. 2013. Assessing the diversity and composition of bacterial communities across a wetland, transition, upland gradient in Macon county Alabama. Diversity 5:461-478 DOI 10.3390/d5030461. 
824 Simachew A, Lanzén A, Gessesse A, Øvreås L. 2015. Prokaryotic community diversity along 825 an increasing salt gradient in a soda ash concentration pond. Microbial Ecology 71:326-

826 338 DOI 10.1007/s00248-015-0675-7.

827

828

829

830

831

832

833

834

835

836

837

838

839

840

841

842

843

844

845

846

Sorokin DY, Trotsenko YA, Doronina NV, Tourova P, Galinski EA, Kolganova TV, Muyzer G. 2007. Methylonatrum kenyense gen. nov., sp. nov., methylotrophic gammaproteobacteria from hypersaline lakes. International Journal of Systematic and Evolutionary Microbiology 57:2762-2769 DOI 10.1099/ijs.0.64955-0.

Sullivan TS, Mcbride MB, Thies JE. 2013. Soil bacterial and archaeal community composition reflects high spatial heterogeneity of $\mathrm{pH}$, bioavailable $\mathrm{Zn}$, and $\mathrm{Cu}$ in a metalliferous peat soil. Soil Biology \& Biochemistry 66:102-109 DOI 10.1016/j.soilbio.2013.06.021.

Tanner MA, Everett CL, Coleman WJ, Yang MM, Youvan DC. 2000. Complex microbial communities inhabiting sulphide-rich black mud from marine coastal environments. Biotechnology et alia 8:1-16.

Tejeda-agredano MC, Gallego S, Vila J, Grifoll M, Ortega-Calvo JJ, Cantos M. 2013. Influence of the sun flower rhizosphere on the biodegradation of PAHs in soil. Soil Biology \& Biochemistry 57:830-840 DOI 10.1016/j.soilbio.2012.08.008.

Tolar BB, King GM, Hollibaugh JT. 2013. An analysis of Thaumarchaeota populations from the northern Gulf of Mexico. Frontiers in Microbiology 4:1-36 DOI 10.3389/fmicb.2013.00072.

Valenzuela-Encinas C, Neria-González I, Alcántara-Hernández RJ, Enríquez-Aragón JA, Estrada-Alvarado I, Hernández-Rodríguez C, Marsch R. 2008. Phylogenetic analysis of the archaeal community in an alkaline-saline soil of the former lake Texcoco (Mexico). Extremophiles 12:247-254 DOI 10.1007/s00792-007-0121-y. 
847 Valenzuela-Encinas C, Neria-González I, Alcántara-Hernández RJ, Estrada-Alvarado I,

848 Zavala-Díaz de la Serna FJ, Dendooven L, Marsch R. 2009. Changes in the bacterial

849 populations of the highly alkaline saline soil of the former lake Texcoco (Mexico)

850 following flooding. Extremophiles 13:609-621 DOI 10.1007/s00792-009-0244-4.

851 Valenzuela-Encinas C, Alcántara-Hernández RJ, Estrada-Alvarado I, Zavala-Díaz de la

852 Serna FJ, Dendooven L, Marsch R. 2012. The archaeal diversity and population in a

853 drained alkaline saline soil of the former lake Texcoco (Mexico). Geomicrobiology

$854 \quad$ Journal 29:18-22 DOI 10.1080/01490451.2010.520075.

855 Vogt JC, Abed RMM, Albach DC, Palinska KA. 2017. Bacterial and archaeal diversity in

856 hypersaline cyanobacterial mats along a transect in the intertidal flats of the sultanate of

857 Oman. Microbial Ecology 1-17 DOI 10.1007/s00248-017-1040-9.

858 Wang Q, Garrity GM, Tiedje JM, Cole JR. 2007. Na1ve bayesian classifier for rapid

859

860 assignment of rRNA sequences into the new bacterial taxonomy. Applied and Environmental Microbiology 73:5261-5267 DOI 10.1128/AEM.00062-07.

Wasserstrom H, Kublik S, Wasserstrom R, Schulz S, Schloter M, Steinberger Y. 2017.

862

Bacterial community composition in costal dunes of the Mediterranean along a gradient

863 from the sea shore to the inland. Scientific Reports 7:1-7 DOI 10.1038/srep40266.

Webster G, Sullivan LAO, Meng Y, Williams S, Sass AM, Watkins AJ, Weightman AJ.

865

2015. Archaeal community diversity and abundance changes along a natural salinity

866 gradient in estuarine sediments. FEMS Microbiology Ecology 91:1-18 DOI

867 10.1093/femsec/.

Wei T, Simko V. 2016. corrplot: visualization of a correlation matrix. R package version 0.77 . Available at https://CRAN.R-project.org/package=corrplot 
870 Wessén E, Söderström M, Stenberg M, Bru D, Hellman M, Welsh A, Hallin S. 2011. Spatial

871 distribution of ammonia-oxidizing Bacteria and Archaea across a 44-hectare farm related

872 to ecosystem functioning. The International Society for Microbial Ecology Journal

$873 \quad$ 5:1213-1225 DOI 10.1038/ismej.2010.206.

874 Winston F, Hoffman CS. 1987. A ten-minute DNA preparation from yeast efficiently releases

875

876 autonomous plasmids for transformation of Escherichia coli. Gene 57:267-272 DOI 10.1016/0378-1119(87)90131-4.

877

878

FURTHER READING

879

880

Bissett A, Richardson AE, Baker G, Wakelin S, Thrall PH. 2010. Life history determines biogeographical patterns of soil bacterial communities over multiple spatial scales.

881 Molecular Ecology 19:4315-4327 DOI 10.1111/j.1365-294X.2010.04804.x.

Bivand RS, Pebesma EJ, Gomez-Rubio V. 2013. Applied spatial data analysis with R, second 883 edition. New York: Springer. Available at http://www.asdar-book.org/.

Ettema CH, Wardle DA. 2002. Spatial soil ecology. Trends in Ecology \& Evolution 5347:177183.

Gallardo A, Maestre FT. 2008. Métodos geoestadísticos para el análisis de datos ecológicos espacialmente explícitos. Capítulo 6. In: Maestre FT, Escudero A, Bonet A, eds. Introducción al análisis espacial de datos en ecología y ciencias ambientales: Métodos y aplicaciones. Madrid: Dikynson, 215-272.

Hanson CA, Fuhrman JA, Horner-Devine MC, Martiny JBH. 2012. Beyond biogeographic 891 patterns: processes shaping the microbial landscape. Nature Reviews Microbiology

892 10:497-506 DOI 10.1038/nrmicro2795. 
893 Hurst CJ, ed. 2016. Their World: A diversity of microbial environments (Vol. 1). Ohio:

894 Springer International Publishing Switzerland DOI 10.1007/978-3-319-28071-4.

895 Jeelani J, Kirmani NA, Sofi JA, Mir SA. 2017. An overview of spatial variability of soil

896 microbiological properties using geostatistics. International Journal of Current

897 Microbiology and Applied Sciences 6:1132-1145 DOI 10.20546/ijcmas.2017.604.140.

898 Jongman RH, Ter Braak CJF, Van Tongeren OFR, eds. 2007. Data analysis in community

899 and landscape ecology. New York, USA: Cambridge University Press, 321.

900 Lauber CL, Strickland MS, Bradford MA, Fierer N. 2008. The influence of soil properties on

901 the structure of bacterial and fungal communities across land-use types. Soil Biology \&

902 Biochemistry 40:2407-2415 DOI 10.1016/j.soilbio.2008.05.021.

903 Ming-Huang P, Li Y, Sumner M, eds. 2012. Handbook of soil sciences: Resource management

904 and environmental impacts, second edition. CRC Press, 818.

905 Nannipieri P, Pietramellara G, Renella G, eds. 2014. Omics in soil science. Norfolk: Caister $906 \quad$ Academic Press, 198.

907 RStudio Team 2012. RStudio: Integrated Development for R. RStudio, Inc., Boston, MA.

908 Available at http://www.rstudio.com/.

909 Treseder KK, Balser TC, Bradford MA, Brodie EL, Dubinsky EA, Eviner VT, Hofmockel

910 KS, Lennon JT, Levine UY, MacGregor BJ, Pett-Ridge J, Waldrop MP. 2011.

911 Integrating microbial ecology into ecosystem models: challenges and priorities.

912 Biogeochemistry 109:7-18 DOI 10.1007/s10533-011-9636-5.

913 Umali P, Oliver DP, Forrester S, Chittleborough DJ, Hutson JL, Kookana RS, Ostendorf

914 B. 2012. The effect of terrain and management on the spatial variability of soil properties

915 in an apple orchard. Catena 93:38-48 DOI 10.1016/j.catena.2012.01.010. 
916 Wallenius K. 2011. Microbiological characterisation of soils: Evaluation of some critical steps

917 in data collection and experimental design. D. Phil. Thesis. University of Helsinki.

$918 \quad$ Available at http://ethesis.helsinkifi/ 


\section{Figure 1}

Correlations between soil characteristics and archaeal groups.

(A) Heatmap with Spearman correlations between archaeal genera and soil characteristics. Positive significant correlations are marked in light blue $(p<0.05)$ and highly significant in dark blue $(p<0.01)$ while negative significant correlations are marked in light red $(p<0.05)$ and highly negative significant in dark red $(p<0.01)$. (B) Canonical analysis of principal coordinates (CAP) site scores (weighted sums of Archaeal group scores), represented as a solid line and (C) Biplot scores for group scores and constraining variables, represented as dotted line. Dimension 1 explained 50.41\% of variability and Dimension 2 17.33\%.

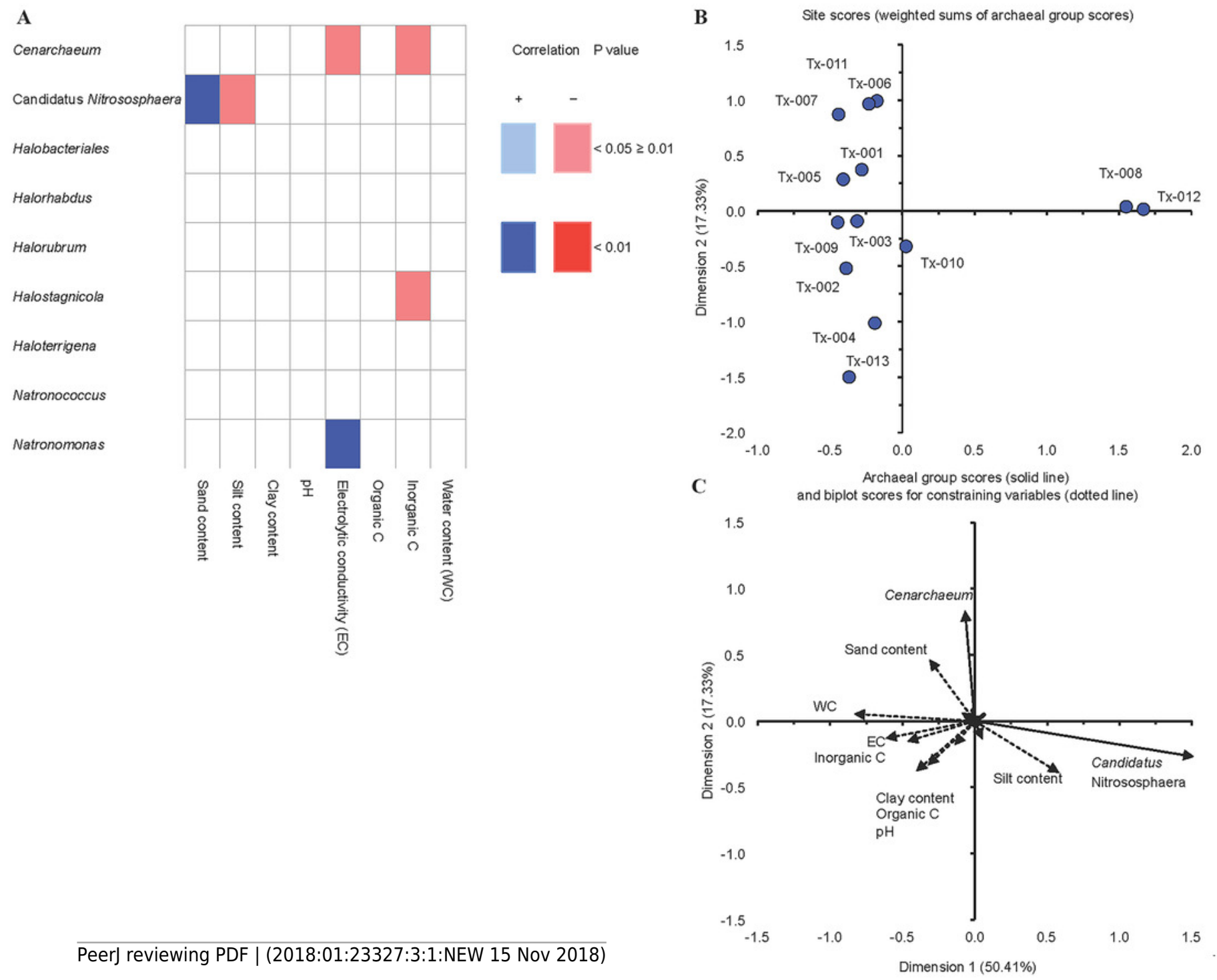


Figure 2

Correlation between bacterial groups and soil characteristics.

Heatmap with Spearman correlations between (A) bacterial phyla or (B) genera and selected soil characteristics. Positive significant correlations are marked in light blue $(p<0.05)$ and highly significant in dark blue $(p<0.01)$ while negative significant correlations are marked in light red $(p<0.05)$ and highly negative significant in dark red $(p<0.01)$.
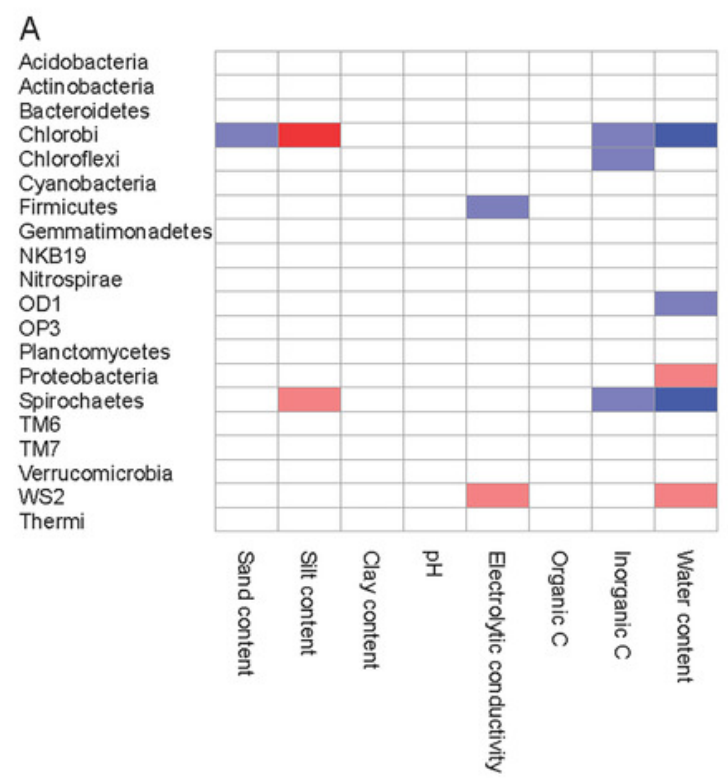

B

Acidovorax Albidovulum Alkalibacillus

Alkalibacterium

Alkaliphilus

Amaricoccus

Anaerobacillus

Aquiflexum

B-42

Bacillus

Carboxydothermus

Chelatococcus

Clostridium

Desulfobacca

Devosia

Euzebya

Gemmata

Halomonas

Halorhodospira

Kaistobacter

KSA1

Legionella

Methylonatrum

Methylonatrum

Mycobacterium
Natronocella

Nesterenkonia

Nitriliruptor

Nocardioides

Nodosilinea

Oceanicella

Paenibacillus

Paracoccus

Phycicoccus

Phytohabitans

Planctomyces

Plesiocystis

Pontibacter

Rhodobaca

Rhodobacter

Rhodobium

Rhodoplanes

Rhodovibrio

Rubricoccus

Sphingobium

Spirochaeta

Staphylococcus

Stenotrophomonas

Synechococcus

Variovorax

Xylanimicrobium
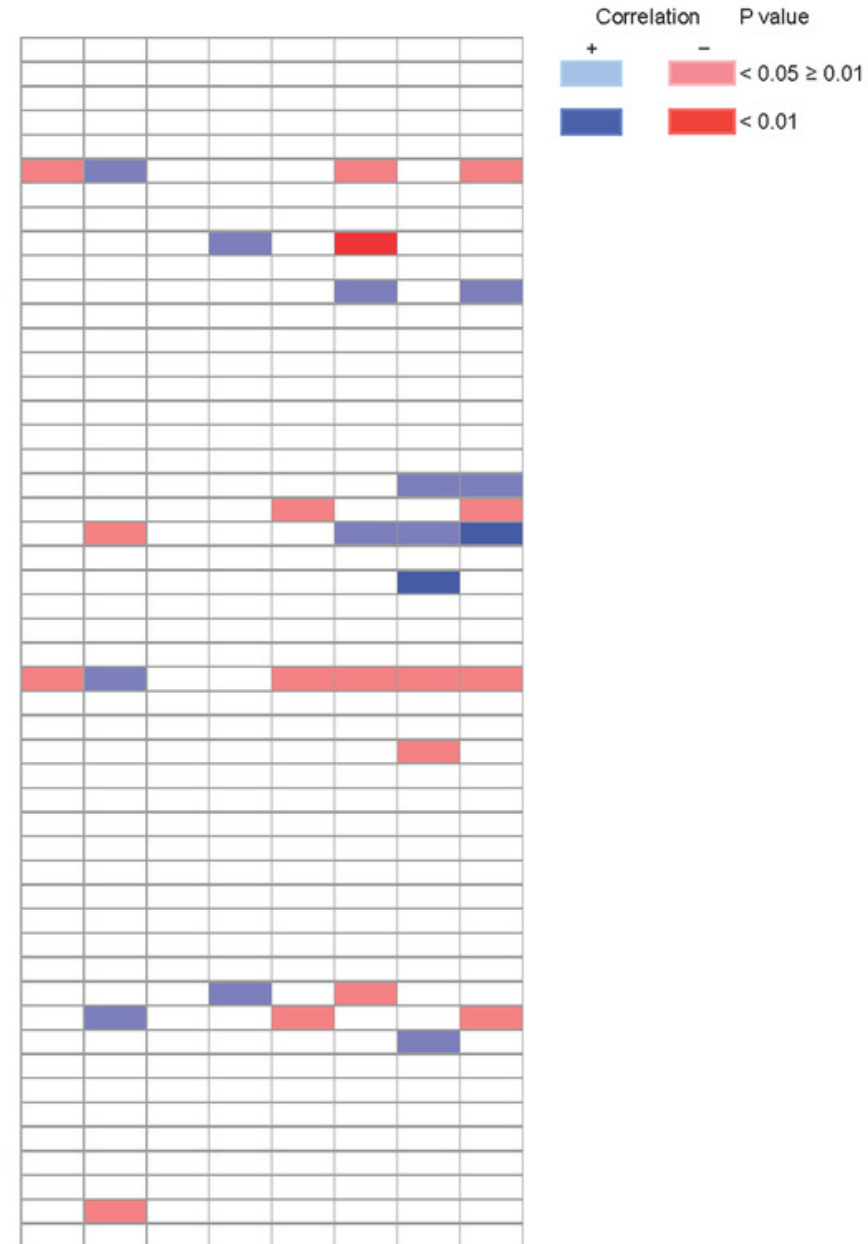

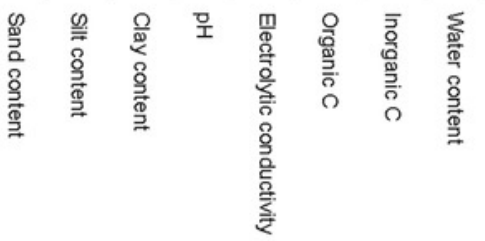




\section{Figure 3}

Canonical analysis of principal coordinates of bacterial groups.

Canonical analysis of principal coordinates (CAP) with site scores (weighted sums of Bacterial group scores) and biplot scores for (A) and (B) bacterial phyla (Dimension 1 explained $42.63 \%$ of the variation and dimension 2 14.51\%), (C) and (D) bacterial genera (dimension 1 explained $32.35 \%$ and dimension $215.71 \%$ of the variation. Bacterial groups scores are represented as a solid line and biplot scores for constraining variables as a dotted line.

A

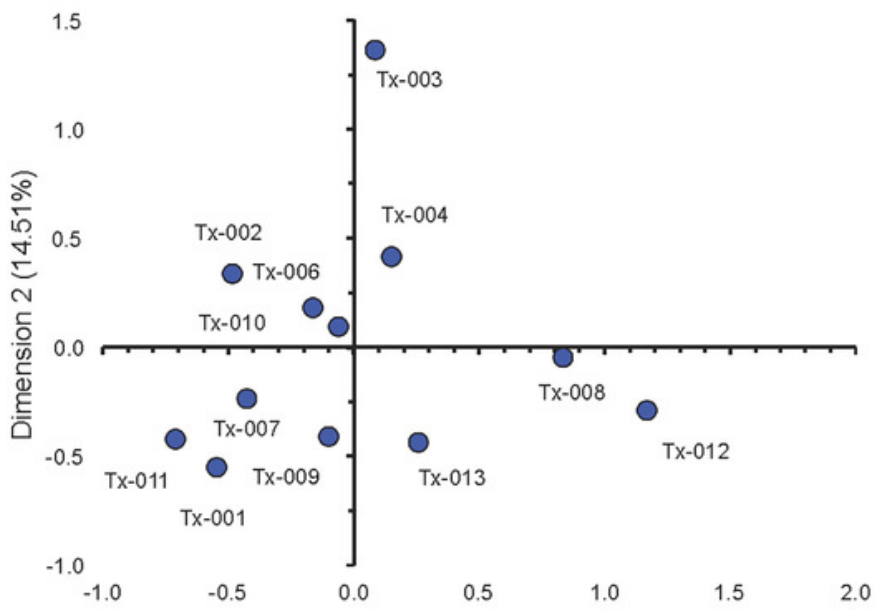

Site scores (weighted sums of Bacterial group scores)

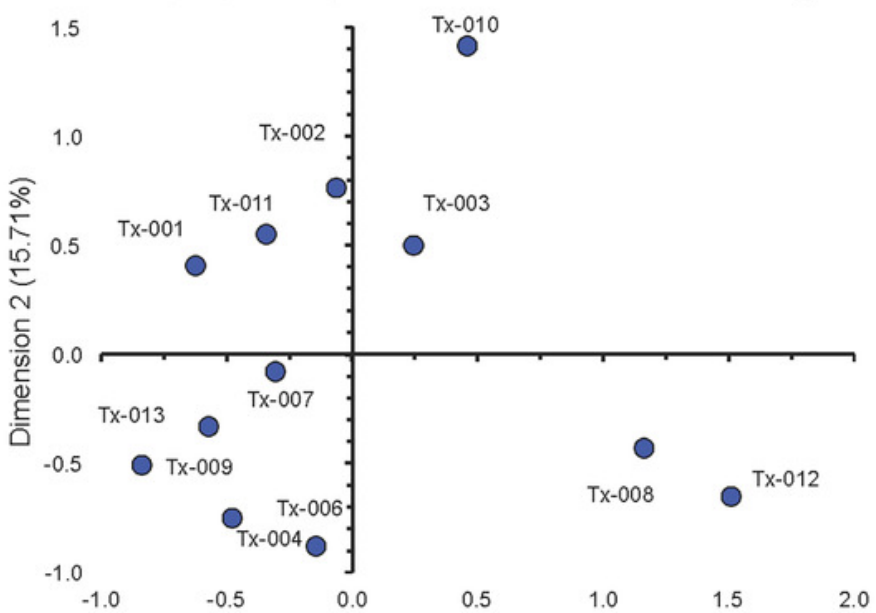

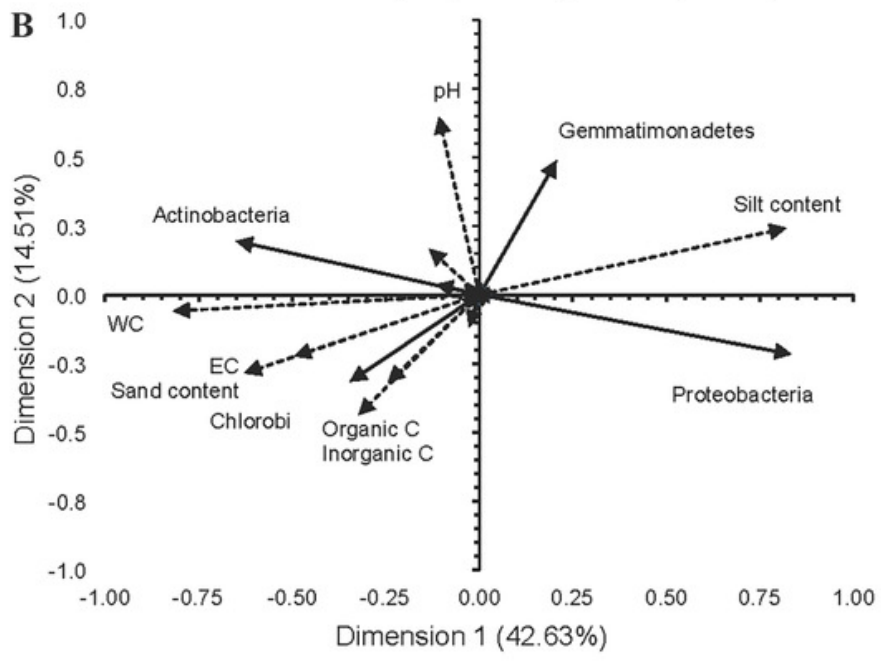

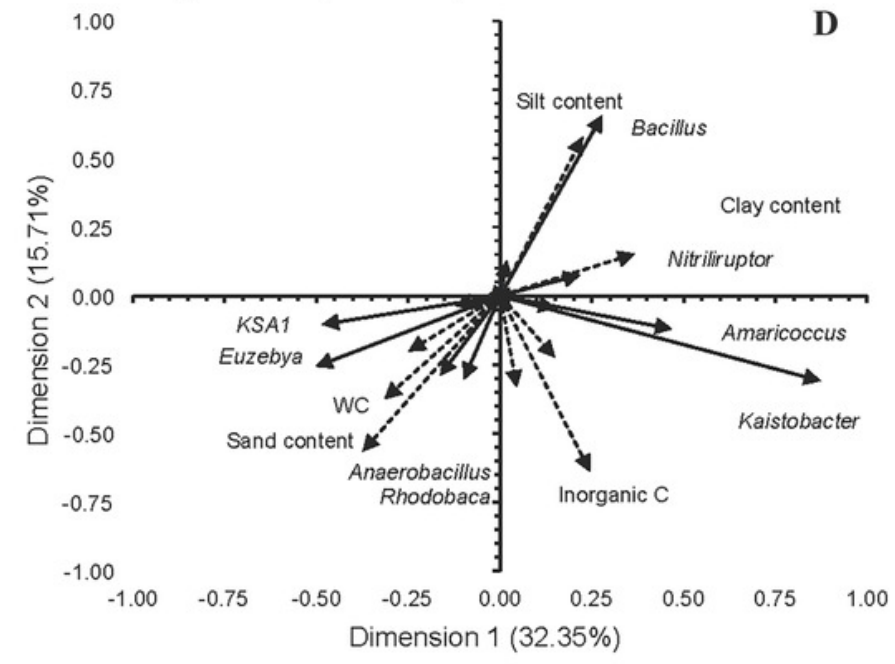




\section{Figure 4}

Ordinary kriging maps of electrolytic conductivity, water content and archaeal phyla.
(A) electrolytic conductivity (EC),
(B) water content (WC),
(C) relative abundance of

Euryarchaeota and (D) relative abundance of Thaumarchaeota. Pred: predicted values by ordinary kriging on a 3000-pixel grid (2.38 $\mathrm{m}^{2}$ each). Obs: observed values at the southeast transect sampling sites (Tx001-Tx013). The coordinates are in UTM (14N).

A

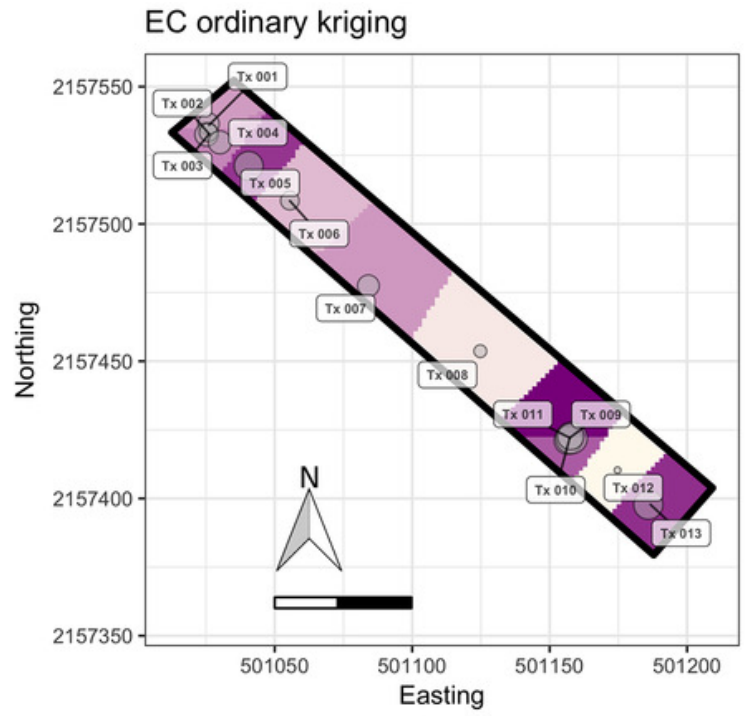

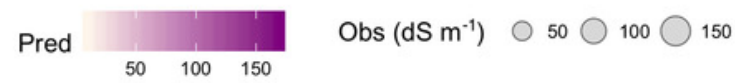

C

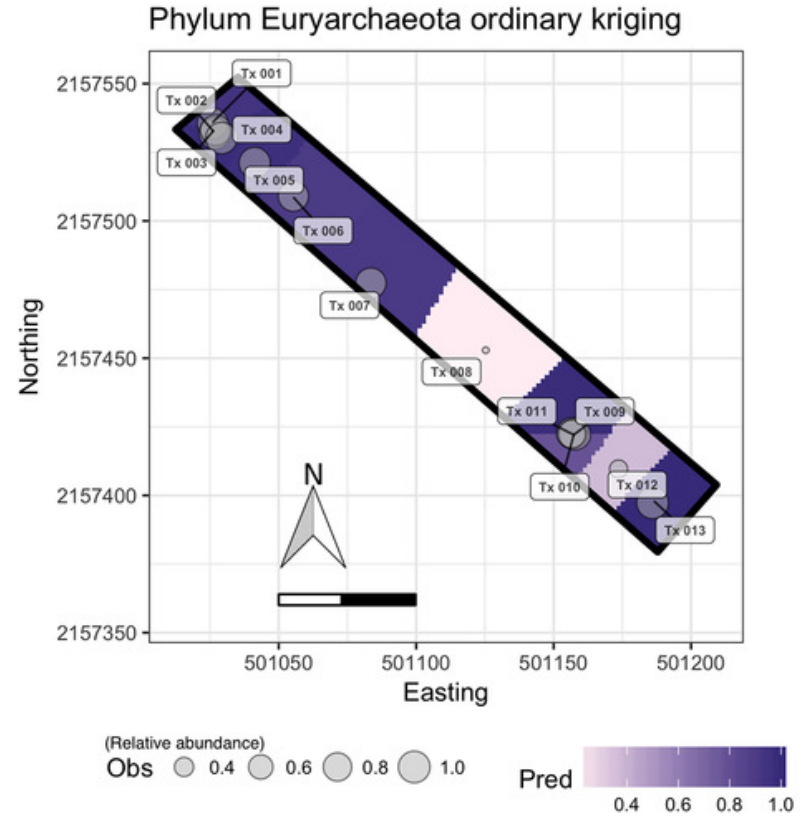

B

Water content ordinary kriging

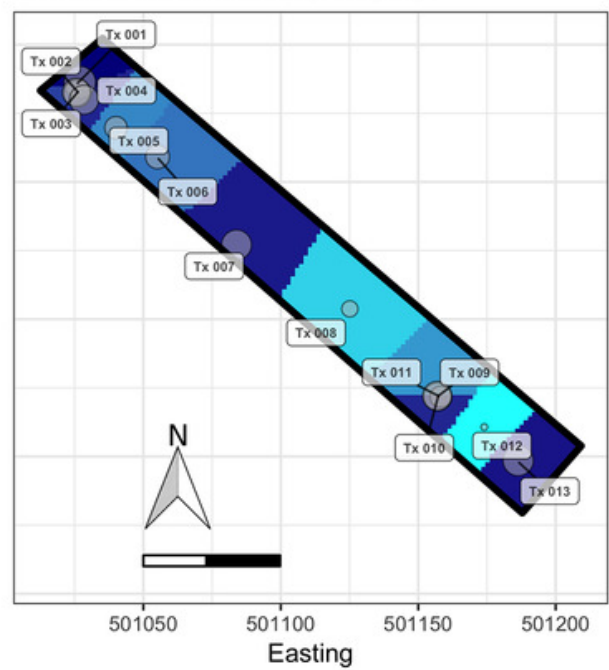

Pred $\begin{array}{llllllll}20 & 30 & 40 & 50 & & & & \end{array}$ Obs ( $\left.\% \quad\right) \quad 20 \bigcirc 30 \bigcirc 40 \bigcirc 50$

Phylum Thaumarchaeota ordinary kriging

D

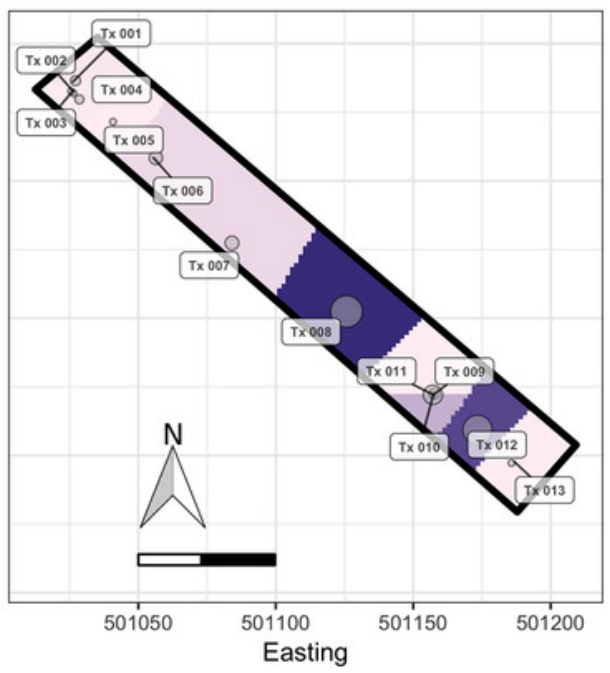

(Relative abundance)

Obs $\circ 0.0 \bigcirc 0.2 \bigcirc 0.4 \bigcirc 0.6$

Pred 
Figure 5

Ordinary kriging maps for $\mathrm{pH}$ and some bacterial phyla.

(A) pH, (B) Actinobacteria, (C) [Thermi], (D) Proteobacteria, (E) Bacteroidetes, (F) Firmicutes.

Pred: predicted values by ordinary kriging on a 3000-pixel grid (2.38 $\mathrm{m}^{2}$ each); Obs: observed values at the southeast transect sampling sites (Tx001-Tx013). The coordinates are in UTM $(14 N)$.
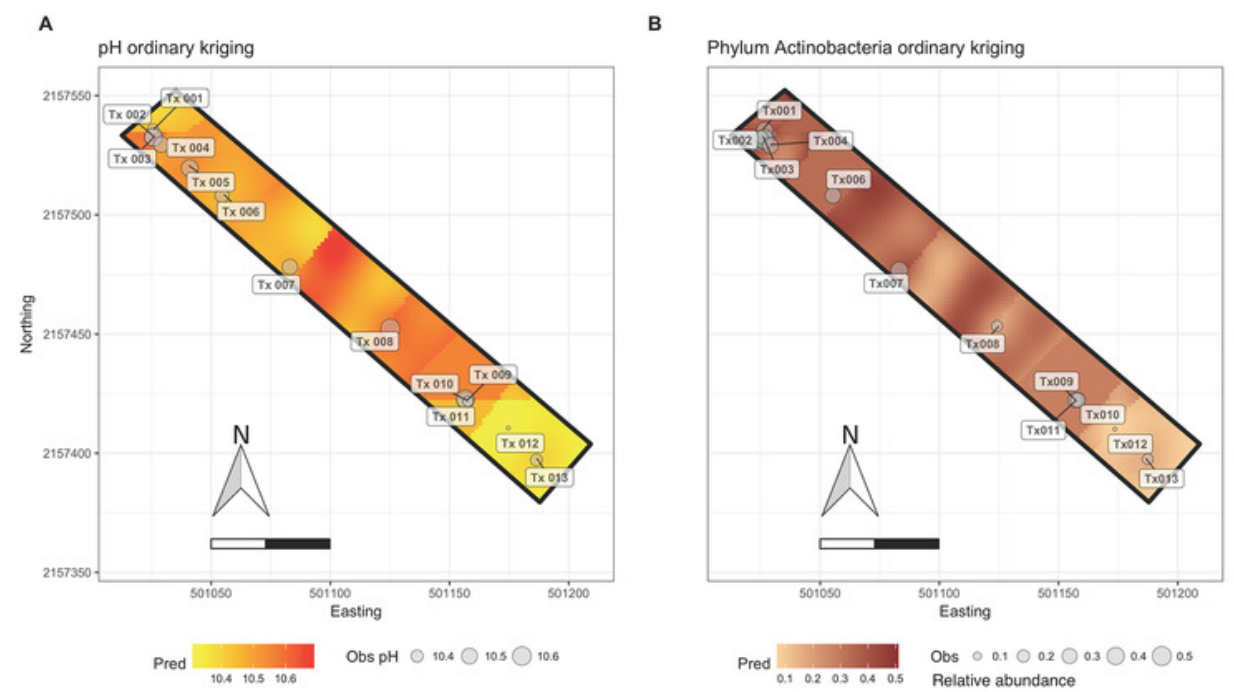

C
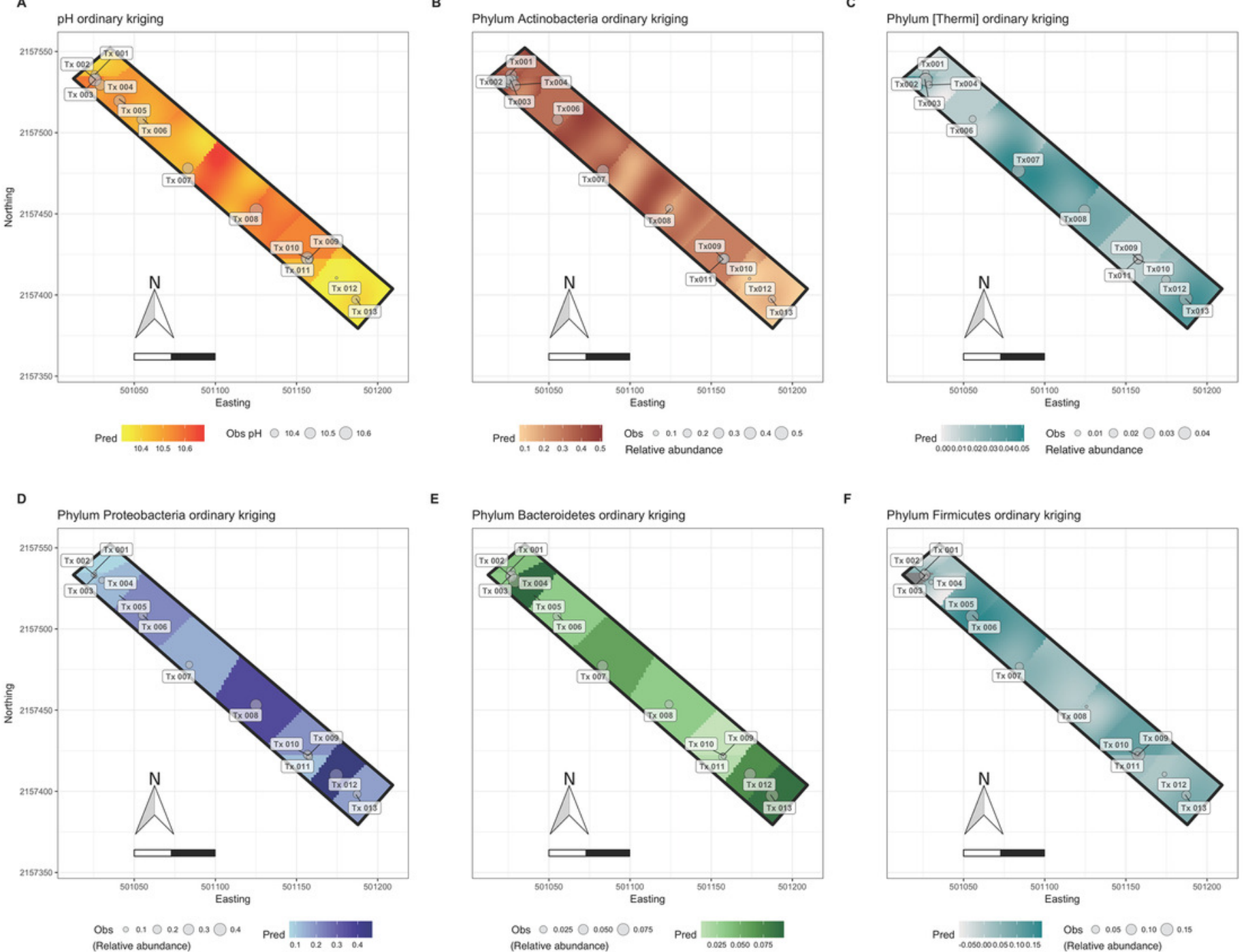

E

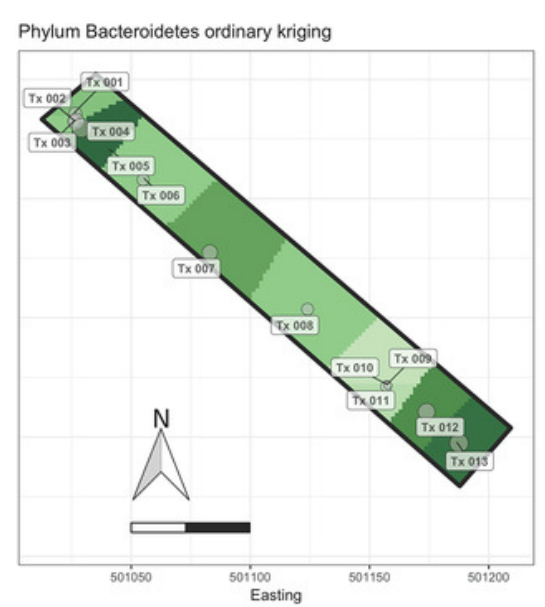

Phylum Firmicutes ordinary kriging

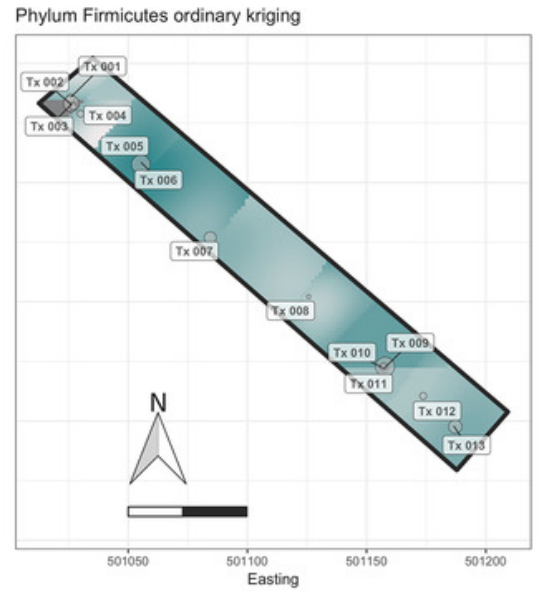

Obs $\bigcirc 0.025 \bigcirc 0.050 \bigcirc 0.075 \quad$ Pred
(Relative abundance)

Pred

Obs $\bigcirc 0.05 \bigcirc 0.10 \bigcirc 0.15$ (Relative abundance) 


\section{Table $\mathbf{1}$ (on next page)}

Archaeal diversity. Diversity indices of the different taxonomic levels of Archaea at each sampling location (Tx001-Tx013) along a southeast transect in soil of the former lake Texcoco.

a after quality filtration, ${ }^{b}$ assigned to that taxonomic level, ' number of OTUs found before the subset was normalized to the sample with the lowest sequence count, 'ACE: Abundancebased Coverage Estimator 


\begin{tabular}{|c|c|c|c|c|c|c|c|c|c|c|c|c|c|c|}
\hline Sample & Tx001 & Tx002 & Tx003 & Tx004 & Tx005 & Tx006 & Tx007 & Tx008 & Tx009 & Tx010 & Tx011 & Tx012 & Tx013 & Total \\
\hline Sequences $^{a}$ & 802 & 1439 & 571 & 160 & 837 & 723 & 1365 & 1225 & 802 & 1112 & 826 & 630 & 927 & 11419 \\
\hline OTU $_{97}{ }^{c}$ & 743 & 1292 & 518 & 152 & 775 & 685 & 1144 & 1187 & 750 & 1011 & 785 & 623 & 868 & 10533 \\
\hline Phylum & 2 & 1 & 1 & 2 & 1 & 2 & 2 & 2 & 2 & 1 & 2 & 2 & 1 & $2^{b}$ \\
\hline Class & 3 & 2 & 2 & 4 & 2 & 3 & 3 & 2 & 2 & 2 & 2 & 3 & 3 & 4 \\
\hline Order & 3 & 2 & 2 & 4 & 2 & 4 & 3 & 2 & 2 & 2 & 2 & 3 & 3 & 5 \\
\hline Family & 3 & 1 & 1 & 2 & 2 & 4 & 2 & 2 & 2 & 1 & 2 & 2 & 1 & 5 \\
\hline Genera & 6 & 5 & 5 & 3 & 3 & 5 & 6 & 3 & 6 & 4 & 5 & 2 & 4 & 9 \\
\hline \multicolumn{15}{|l|}{ Diversity parameters } \\
\hline Shannon & 5.24 & 5.15 & 5.01 & 5.61 & 5.33 & 4.79 & 5.87 & 2.10 & 5.66 & 4.72 & 5.31 & 2.87 & 5.60 & \\
\hline Simpson & 0.95 & 0.94 & 0.94 & 0.97 & 0.94 & 0.91 & 0.97 & 0.49 & 0.97 & 0.91 & 0.94 & 0.70 & 0.96 & \\
\hline Simpson E & 0.33 & 0.27 & 0.28 & 0.48 & 0.25 & 0.20 & 0.48 & 0.07 & 0.45 & 0.20 & 0.25 & 0.14 & 0.39 & \\
\hline Simpson Reciprocal & 21.26 & 17.42 & 16.70 & 33.03 & 17.11 & 11.47 & 39.03 & 1.95 & 32.15 & 11.37 & 17.55 & 3.29 & 28.54 & \\
\hline Chao1 & 211.9 & 159.1 & 113.1 & 147.8 & 132.1 & 105.5 & 259.6 & 56.6 & 162.1 & 180.0 & 299.7 & 30.0 & 162.4 & \\
\hline Good's Coverage & 0.67 & 0.67 & 0.73 & 0.68 & 0.68 & 0.74 & 0.55 & 0.87 & 0.66 & 0.70 & 0.62 & 0.94 & 0.63 & \\
\hline Phylogenetic diversity & 2.89 & 2.83 & 2.61 & 3.39 & 3.24 & 3.21 & 3.82 & 1.79 & 3.27 & 2.20 & 3.63 & 1.58 & 3.15 & \\
\hline ACE $^{d}$ & 239.55 & 218.11 & 165.55 & 175.18 & 164.38 & 145.56 & 355.46 & 86.20 & 182.63 & 216.98 & 257.60 & 31.56 & 228.47 & \\
\hline
\end{tabular}




\section{Table 2 (on next page)}

Bacterial diversity. Diversity indices of the different taxonomic levels of Bacteria at each sampling location (Tx001-Tx013) along a southeast transect in soil of the former lake Texcoco.

${ }^{a}$ after quality filtration, ${ }^{b}$ assigned to that taxonomic level, ${ }^{c}$ number of OTUs found before the subset was normalized to the sample with the lowest sequence count, ${ }^{\mathrm{d}}$ ACE: abundancebased coverage estimator 


\begin{tabular}{|c|c|c|c|c|c|c|c|c|c|c|c|c|c|}
\hline Sample & Tx001 & Tx002 & Tx003 & Tx004 & Tx006 & Tx007 & Tx008 & Tx009 & Tx010 & Tx011 & Tx012 & Tx013 & Total \\
\hline Sequences $^{a}$ & 668 & 676 & 436 & 323 & 231 & 794 & 304 & 700 & 297 & 245 & 280 & 167 & 5121 \\
\hline OTU $_{97}{ }^{c}$ & 511 & 558 & 346 & 309 & 217 & 706 & 266 & 641 & 278 & 220 & 232 & 155 & 4439 \\
\hline Class & 16 & 18 & 11 & 20 & 14 & 21 & 19 & 22 & 16 & 17 & 21 & 21 & 43 \\
\hline Order & 14 & 15 & 12 & 18 & 15 & 17 & 17 & 19 & 15 & 18 & 18 & 21 & 44 \\
\hline Family & 14 & 15 & 12 & 15 & 14 & 18 & 19 & 19 & 14 & 15 & 16 & 17 & 55 \\
\hline Shannon & 5.52 & 5.92 & 5.96 & 6.12 & 5.74 & 6.21 & 5.72 & 6.11 & 5.52 & 5.75 & 5.57 & 6.13 & \\
\hline Simpson & 0.96 & 0.98 & 0.97 & 0.98 & 0.98 & 0.98 & 0.97 & 0.98 & 0.97 & 0.98 & 0.97 & 0.98 & \\
\hline Simpson E & 0.40 & 0.54 & 0.48 & 0.66 & 0.64 & 0.71 & 0.58 & 0.71 & 0.47 & 0.61 & 0.60 & 0.78 & \\
\hline Simpson Reciprocal & 27.08 & 42.34 & 38.77 & 54.82 & 42.81 & 61.27 & 39.16 & 57.23 & 29.99 & 41.67 & 35.11 & 61.27 & \\
\hline Chao1 & 323.00 & 349.14 & 207.43 & 178.06 & 130.08 & 197.24 & 93.25 & 168.35 & 132.33 & 129.50 & 70.00 & 126.00 & \\
\hline
\end{tabular}

